\title{
Sedimentological and Geochemical evidence for Seismoturbidite Generation in the Kumburgaz Basin, Sea of Marmara: Implications for Earthquake Recurrence along the Central High Segment of the North Anatolian Fault
}

\author{
Yakupoğlu Nurettin ${ }^{1,{ }^{*}}$, Uçarkuş Gülsen ${ }^{1}$, Kadir Eriş K. ${ }^{1}$, Henry Pierre ${ }^{2}$, Namık Çağatay M. ${ }^{1}$
}

${ }^{1}$ Istanbul Technical University, Geological Engineering Department and EMCOL, 34469, Faculty of Mines, Ayazağa, İstanbul, Turkey

${ }^{2}$ CEREGE (UMR7330), Aix-Marseille University, CNRS-IRD, 13330, Marseille, France

* Corresponding author : Nurettin Yakupoğlu, email address : yakupoglu@itu.edu.tr

\begin{abstract}
:
Holocene earthquake history of the Central High Segment of the North Anatolian Fault is examined here for the first time based on analysis of seismoturbidites within a 21-m-long piston core recovered from the Kumburgaz Basin in the Sea of Marmara. The visual lithological description combined with detailed grainsize analyses indicate that the deep basin hemipelagic sediments are interrupted by 28 turbidite units during the last $6.1 \mathrm{cal}$ kyrs BP. The turbidites show strong segregation and a sharp boundary between a coarse basal part and overlying homogenite as inferred from detailed sedimentological and geochemical data. Several amalgamated turbidites are recognized by repeated fining upward sequences with no intervening homogenite indicating multiple episodes of traction and deposition as a result of various slope failures and turbidity currents. Each unit was possibly triggered by the same earthquake event rupturing in the Sea of Marmara. The most common sedimentary feature is the continuous parallel lamination that was presumably introduced by long lasting water oscillations on suspended sediments due to the seiche effect. The establishment of geochemical criteria and exclusive sedimentary processes distinguish earthquake triggered turbidites (seismoturbidites) from other trigger factors. Moreover, such distinction allows us to evaluate hydrodynamic sedimentary conditions and processes in the Kumburgaz Basin. The base of most seismoturbidites are associated with a sharp increase in Mn concentration that can be explained by a diagenetic enrichment of $\mathrm{Mn}$ at the oxic/anoxic interface of the sediments near the seafloor prior to the deposition of the turbidite. An age-depth model of the studied core based on seven AMS 14C ages allows precise correlation between historical earthquakes and seismoturbidites in the Kumburgaz Basin. At least the latest nine of them fit well with the previously recorded major earthquake events between ca. $\sim 500$ cal yrs. BP and 2.5 cal kyrs BP.
\end{abstract}

Keywords : Earthquake geology, Seismoturbidite, Kumburgaz Basin, Sea of Marmara, North Anatolian Fault 

paleoseismology to unravel earthquake cycles adjacent to plate boundaries and regions with regular seismic activity. These deposits are studied by using various proxies in regions; the North San Andreas Fault and Cascadia subduction zone (Adams, 1990; Goldfinger et al., 2003, 2007, 2008, 2011, 2017), New Zealand (Pouderoux et al., 2012a,b; Barnes et al., 2013), the Mediterranean (Kastens and Cita, 1981; Cita et al., 1982, 1984, 1996; Kastens, 1984; Cita and Aloisi, 2000; Polonia et al., 2013a, 2017), the west coast of Iberian Peninsula (Gracia et al., 2000; Masson et al., 2011), and in Japan Sea (Nakajima and Kanai, 2000). than other possible mechanisms such as; storm waves, hyperpycnal flows, gas hydrate 45 dissociation, sediment overloading, volcanic eruptions and floods (Postma et al., 1988; Prior et al., 1989; Nemec, 1990; Mulder and Syvitski, 1995; Beck et al., 1996, 2007; Chapron et al., 1999; Cita and Aloisi, 2000; Nakajima and Kanai, 2000; Shiki et al., 2000; Arnaud et al., 2002; 
based on core and seismic data have been proposed to distinguish seismoturbidites from turbidites of other origins in submarine paleoseismological studies (Nakajima and Kanai, 2000; McHugh et al., 2011; Çağatay et al., 2012; Eriş et al., 2012; Avşar et al., 2015; Goldfinger et al., 2017; Polonia et al., 2017), their origin and depositional processes are still a matter of debate.

After the devastating 1999 Izmit (Mw 7.4) and Düzce (Mw 7.2) earthquakes, submarine paleoseismological studies have become crucial to constrain the earthquake recurrence history of the North Anatolian Fault (NAF) in the Sea of Marmara (SoM) (Sar1 and Cağatay, 2006, McHugh et al., 2006, Beck et al., 2007) (Fig. 1). It is well known that the Northern Branch of the North Anatolian Fault (NNAF) has generated more than $55(\mathrm{Ms}>6.8)$ earthquakes in the SoM region within the last two millennia (Ambraseys and Finkel, 1991, 1995; Guidoboni et al., 1994; Ambraseys and Jackson, 2000; Ambraseys, 2002). These past earthquakes were the dominant triggering mechanism for the failure of unconsolidated sediment on the northern shelf slopes of the SoM (Sarı and Cağatay, 2006; McHugh et al., 2006; Beck et al., 2007; Çăgatay et al., 2012; Eriş et al., 2012; Drab et al., 2012, 2015).

Since the deep sedimentary sub-basins in the northern SoM are aligned along the segments of the highly active dextral strike slip NNAF (Reilinger, 1997; Straub et al., 1997; McClusky et al., 2000; Flerit et al., 2003; Reilinger et al., 2006) (Fig. 1), the sedimentary sequences of the sub-basins have been interpreted to consist predominantly of turbidites of seismic origin (McHugh et al., 2006; Sarı and Çağatay, 2006; Beck et al., 2007; Çağatay et al., 2012; McHugh et al., 2014; Drab et al., 2015). These unique sedimentary units provide an important archive of long-term earthquake activity. Previous models on the distribution of palaeoevents on each individual segment suggest a non-periodic/quasiperiodic behavior for the NNAF in the SoM (Fig. 11 and Table 3 in Drab et al., 2015; Fig. 9 in McHugh et al., 2014). 
Establishing a reliable paleoseismological record in the SoM will allow us to better evaluate the earthquake hazard risk for the region and İstanbul ( $\sim 19 \mathrm{~km}$ north of the NNAF) (Fig. 1). The Central High Segment, which crosses the Kumburgaz Basin, has not had any major earthquakes at least for the last 250 yrs (Parsons et al., 2000; Parsons, 2004; Pondard et al., 2007) (Figs. 1,2). The instrumental seismicity shows sparse activity along the segment and geodetic studies found a large uncertainty on the inter-seismic fault loading rate in this segment (Ergintav et al., 2014; Sakic et al., 2016; Klein et al., 2017). Since the earthquake recurrence intervals were not well resolved on the Central High Segment, the Kumburgaz Basin stands out as an important location to study submarine paleoseismology (Fig. 2). Most of the submarine paleoseismology studies in the sub-basins of the SoM were based on the cores collected in the Tekirdağ, Central and Çınarcık basins (McHugh et al., 2006; Sarı and Çağatay, 2006; Beck et al., 2007; Çağatay et al., 2012; McHugh et al., 2014; Drab et al., 2015). These previous studies proposed some criteria to identify seismoturbidites, which still need improvements to understand their own depositional conditions and processes.

In this study, we present detailed sedimentological and geochemical analysis of a 21-mlong giant piston core recovered from the Kumburgaz Basin. Our main objective is to establish reliable criteria for identifying seismoturbidites on the basis of multi-parameter proxies from sedimentological and geochemical analyses. We also use ${ }^{14} \mathrm{C}$ ages to constrain an age-depth model to evaluate the Late Holocene earthquake records within the piston core and relate the seismoturbidites to historical earthquakes in the catalogues (Ambraseys and Finkel, 1991, 1995; Guidoboni et al., 1994, 2005; Ambraseys, 2002; Altınok et al 2011).

\section{Oceanographic and geologic setting}

The SoM is located in the western part of the $1600-\mathrm{km}$ long North Anatolian Fault Zone that forms a $270-\mathrm{km}$ long and $80-\mathrm{km}$ wide intracontinental marine basin between the Mediterranean and the Black Sea (Fig. 1). It is connected to the low-salinity Black Sea via the Bosphorus and 
to the marine Aegean Sea via the Çanakkale Strait (Dardanelles). These two straits have sill depths of approximately 65 and 35 m, respectively (Ryan et al., 1997; Ryan, 2007; Gökaşan et al., 2008; Eriş et al., 2008). The shallow sill depths of the straits result in a modern two-layer flow system in the SoM with a halocline at $25 \mathrm{~m}$ (Ünlüata et al.,1990; Beşiktepe et al.,1994). Surface water circulation of the SoM forms an anticyclonic loop, due to the difference of water level between the Mediterranean and Black sea (Beşiktepe et al., 1994). Especially during summer to late autumn, surface water originating from the Black Sea flows through Bosphorus, impacting surface water circulation in the SoM. Incoming Mediterranean waters via the Çanakkale Strait induce bottom currents between water depths of $100 \mathrm{~m}$ and $500 \mathrm{~m}$ (Ünlüata et al., 1990). Deep waters of the Kumburgaz Basin are influenced by this salty deep water current (Beşiktepe et al., 1994). The surface and deep water masses in the SoM have the renewal time of 4-5 months and 6-7 years, respectively (Beşiktepe et al., 1994).

The NAF diverges into two main branches before entering into the SoM, a northern branch and a southern branch (Fig. 1). Based on GPS rates, the total slip rate of the NAF is 24$26 \mathrm{~mm} / \mathrm{yr}$ and the most active northern branch (NNAF) accommodates $60-80 \%$ of the total plate motion (Reilinger, 1997; Straub et al., 1997; McClusky et al., 2000; Le Pichon et al., 2001, 2015; Armijo et al., 2002; Provost et al., 2003; Flerit et al., 2003; Şengör et al., 2005; Reilinger et al., 2006; Grall et al., 2013). The NNAF exhibits a segmented submarine fault zone which comprises the main İzmit, Prince's Island, Central High and Tekirdağ fault segments (Fig. 1). Four deep sedimentary basins are aligned along the submerged section of the NNAF. West to east, Tekirdağ (-1133 m), Central (-1268 m), and Çınarcık (-1276 m) basins are bounded by two major ridges which form the Western and Central highs (Fig. 1). The Kumburgaz Basin is located on the Central High with a maximum depth of 833 m (Figs. 1,2). The SoM deep basins contain up to $6 \mathrm{~km}$ thick sediments as observed in deep seismic profiles (e.g., Carton et al., 2003; Laigle et al., 2008), suggesting active subsidence. 


\section{Kumburgaz Basin: bathymetry and morphology}

Kumburgaz Basin is located on the Central High and bisected by the Central High Segment of the NNAF (Figs. 1,2). The basin is elongated in the NE-SW direction and formed at a releasing bend of the NNAF (Fig. 2). Compared to deep basins of the SoM (Çinarcık, Central and Tekirdağ), the Kumburgaz Basin is shallower in depth $(-833 \mathrm{~m})$ and smaller in size. The eastern part of the basin is bounded by a submarine ridge, displaying $3.5-4 \mathrm{~km}$ offset with a right lateral motion related to the NNAF (Armijo et al., 2002) (Figs. 1,2). Kumburgaz basin is bordered by the Central Basin in the west and Çınarcık Basin in the east. The northern slope $\left(9^{\circ}-12^{\circ}\right)$ of the Kumburgaz Basin which has a $\sim 90 \mathrm{~m}$ shelf break, is marked by scars of old submarine landslides and erosive features, most of which were probably enhanced by earthquake activity along the NNAF (Fig. 2) (Görür and Çağatay, 2010; Özeren et al., 2010; Çağatay et al., 2015b). The southern margin of the basin is bounded by a low-lying ridge, having a minimum depth of $-380 \mathrm{~m}$ (Fig. 1).

Three main submarine canyons (Fig. 2) and their tributaries are presumably the main providers of turbidity currents to the Kumburgaz Basin floor. These canyons originate near the continental-shelf break and extend to the base of the continental slope. The northeastern canyon (NEC) is deflected by the NNAF and is the smallest of the three. The north western canyon (NWC) is the longest canyon showing branching towards the shelf edge and a straight course towards the base. The northern canyon (NC) and its tributaries spread with several branches along the northern slope (Fig. 2). The bathymetry and the slope gradient model expose two depocenters in the Kumburgaz Basin (Fig. 2). The eastern depocenter is larger and elongated while the western depocenter is smaller and located at the mouth of the NWC (Fig. 2). Additionally, there is a bathymetric barrier (BB) at the toe of NEC, having ca. $300 \mathrm{~m}$ length and $75 \mathrm{~m}$ height (Figs. 2,3).

\section{Methods \& Instruments}




\subsection{Core recovery and material}

A giant piston core CS-01 (21 m long) was recovered from $\sim 833 \mathrm{~m}$ water depth in the eastern depocenter of the Kumburgaz Basin during the "MARsite" Cruise by R/V Pourquoi pas? (Figs. 2,3). Core recovery was performed by using a Calypso piston corer. Core location was chosen by using sediment sounder (chirp) profiles (Fig. 3). The core was split into 1-meterlong sections, photographed, described and sampled at Istanbul Technical University (ITU) East Mediterranean Centre for Oceanography and Limnology (EMCOL). Core sections were split into working and archive halves. Working halves were used for lithostratigraphic studies and sampling for grain size, smear slide and radiocarbon analyses. The archive halves were used for $\mu$-XRF (X-ray Fluorescence) and Multi Sensor Core Logger (MSCL) analyses and then placed in the core repository of ITU-EMCOL.

\section{2. $\mu$-XRF core analysis}

Core CS-01 was analyzed by Itrax XRF Core Scanner (with Mo X-ray tube, at $30 \mathrm{kV}$, $50 \mathrm{~mA} ; 1 \mathrm{~mm}$ resolution, $10 \mathrm{~s}$ for each measurement time) at ITU-EMCOL Core Analysis Laboratory. The relative elemental abundances of $\mathrm{Fe}, \mathrm{Ca}, \mathrm{Sr}, \mathrm{K}$, and $\mathrm{Mn}$ were recorded as counts per second (cps). Both $\mathrm{Mn}$ and Fe are redox sensitive elements. However, we normalized $\mathrm{Mn}$ and $\mathrm{Fe}$ elements with $\mathrm{Ca}$ to prevent carbonate dilution effect. $\mathrm{Mn} / \mathrm{Ca}$ is mainly used for determination of migrating redox fronts due to the accumulation of gravity flow deposits (Hofmann, 1999; Çağatay et al., 2012). Fe/Ca can display both redox sensivity (showing positive anomalies on Fe monosulfides) and detrital input. $\mathrm{Ca}$ and $\mathrm{Sr}$ are indicators of carbonate content, mainly of biogenic origin in the SoM. Abundance of $\mathrm{K}$ is related to detrital input, and correlate with fine silt and clay size minerals (e.g., illite, mica, feldspar).

\subsection{Physical properties and grain-size analyses}


The physical properties (gamma density and magnetic susceptibility) of the core were measured on the archive-half at $1 \mathrm{~cm}$ resolution using a Geotek MSCL at the ITU-EMCOL core analysis laboratory. Magnetic susceptibility (M.S.) analysis was performed by using a Bartington point sensor. Positive M.S. anomalies are in general related to terrigenous input. Gamma-ray density is related with density and porosity and sorting of the material. Grain-size analysis of the core was performed with $5 \mathrm{~cm}$ sampling interval using Malvern Mastersizer 3000 Grain-Size Analyzer without any pretreatment due to lack of macro fossil assemblages. Grain-size distribution of turbidites is determined with $0.5 \mathrm{~cm}$ sampling interval in order to obtain higher resolution grain-size parameters (sorting and skewness). The grain-size fractions (sand, silt and clay) for each seismoturbidite unit in the core were calculated according to the Wentworth scale (Wentworth, 1922). Mineral composition and benthic foraminifera identification in the turbidite units were made on the sieved $>63 \mu \mathrm{m}$ fraction at $0.5 \mathrm{~cm}$ sampling interval.

\subsection{Radiocarbon Analysis and Age-depth model}

AMS ${ }^{14} \mathrm{C}$ analyses of 7 samples were carried out at the ARTEMIS CNRS facility (Gifsur-Yvette). Hemipelagic sediment samples from beneath the mass-flow units were wet-sieved and $>63 \mu \mathrm{m}$ fractions were used to hand-pick carbonate shell material under binocular microscope. Because the radiocarbon datable shell material was scarce in the samples, we also included epifaunal benthic foraminifera, echinoderm spicules and occasionally bivalve shells, in addition to the planktonic foraminifera. Care was taken to sample shells without evidence of reworking and diagenesis. All samples were washed in distilled water and dried (at $40^{\circ} \mathrm{C}$ ) before the analysis. Results were calibrated using Calib v7.0 software with Marine13.14C calibration curve and a reservoir age correction of $390 \pm 85$ (Sinai et al., 2000) (Table 1). Inclusion of benthic and pelagic shells in the same sample would not affect the reservoir age because of the negligible difference (6-7 years) between the residence time of upper and lower water masses 
in the SoM (Beşiktepe et al., 1994). Calibrated ages were processed with R-studio using the script "bacon.r", based on Bayesian statistics, to obtain an age-depth model for the core's sedimentary sequence, ignoring the mass-flow units. The script created age-depth models, calculating the 95\% Gaussian confidence interval around the best model (Fig. 5).

\section{Results}

\subsection{Lithostratigraphy and chronostratigraphy}

The studied core CS-01 includes a sedimentary succession that was deposited after the latest marine connection of the SoM, sometime between 14.7-12.5 kyrs BP (Çağatay et al., 2000, 2003, 2015; Vidal et al., 2010; Eriş et al., 2011, 2012). This 21 m-long succession represents a continuous record of the last $\sim 6.1$ cal. kyrs BP (Table 1, Figs. 4, 5). and is correlated with upper part the sequence observed in $3.5 \mathrm{kHz}$ seismic lines (Fig. 3).

Core CS-01 consists of continuous "background" hemipelagic/pelagic sediments that are interrupted by 28 turbidite layers identified by visual lithology and textural properties (Fig. 4). Through the core, the 'background' sedimentation is slightly variable in terms of siliciclastic (clay-silt) and calcareous fractions. In the first two meters, a gradual downward change in color from brownish (oxidized mud) to olive gray is observed, and thereafter the sediment color changes to gray and then dark gray between $3 \mathrm{~m}$ and $15 \mathrm{~m}$. The rest of the core is represented by a dark greenish gray silty clay (Fig. 4). In general, the background sediments in the core display homogenous texture without distinct variations in internal sedimentary structures. The detrital carbonate grains are commonly more abundant than the biogenic components. Fesulfide nodules (pyrite) and patches (iron-monosulfides) are scattered throughout the core. The fine-grained 'background' is locally dominated by benthic foraminifera assemblages such as ammodiscus sp., textularia sp., spiroloculina sp., quinqueloculina sp., binoculina sp., triloculina sp., dentalina sp., amphicoryna sp., lagena sp., bolivina sp., brizalina sp., bulimina sp., uvigerina sp., chilostomella sp. and ammonia sp. However, turbidite-homogenite units are 
only dominated by bivalve fragments, echinoderm spicules, ammonia sp., elphidium sp., uvigerina sp. and quinqueloculina sp. fossils.

\subsection{Sedimentological characteristics of turbidites}

A total of 28 turbidite units consisting of a basal coarse part and the overlying homogeneous mud (homogenite) were identified lithologically and labeled as ST-1 to ST-28. Their thicknesses range from $2 \mathrm{~cm}$ to $25 \mathrm{~cm}$. The total thickness of the turbidites make up $18 \%$ of the $21 \mathrm{~m}$-long sedimentary succession in the core. This ratio of turbidite to background hemipelagic sediment in the Kumburgaz Basin is low compared to the ratios (up to $75 \%$ turbidites) in the other SoM basins (Beck et al., 2007; Çağatay et al., 2009; Eriş et al., 2012) (Fig. 1).

The lower boundary of the coarse basal part of the turbidites with the underlying hemipelagic sediments in the Kumburgaz Basin is sharp, but commonly non-erosional. Grainsize fluctuations in the coarser basal part are documented as alternations of normal and reverse grading, producing the thin parallel laminations observed in the core, radiographic images and grain-size distributions (Figs. 6,7). According to the classification of Folk (1980), basal units of the turbidites show very poorly sorted texture (ranging between 2-3) and positively skewed distribution (ranging between 0 to $\sim 0.3$ ) (Figs. 6,7). Smear slide microscopic observations show that most sand particles have pitted surfaces. The basal part also contains a high amount of fossils and fossil fragments of bivalves, echinoid spicules and benthic foraminifera relative to background sediments. The abrupt lithological change between the lower coarse basal parts and the upper homogeneous parts can be detected in the grain-size distribution, gamma density profiles and X-ray images (Fig. 6). Some turbidites in the core are stacked on top of each other without any interbedded homogenite part or hemipelagic sediments, showing the properties of amalgamated turbidites (Polonia et al., 2017) (Fig. 7). 
Homogenite part of the turbidites represents the turbidite tail deposits and identified as homogenous mud in the visual description. This part consists of clay to fine silt fractions with

247 a fining upward trend in grain size. Homogenite has higher gamma density values (1.59-1.62 $\mathrm{gr} / \mathrm{cc}$ ) than the hemipelagic sediments $(1.57-1.59 \mathrm{gr} / \mathrm{cc}$ ) (Fig. 6). The homogenite part is marked by poorly sorted (1.7-2) and positively skewed (0.1-0.3) sediments that are compatible with grainsize fractions, since hemipelagic sediments are dominated by finer grain size fractions (lower than $8 \mu \mathrm{m}$ ) (Fig. 6). Therefore, the overlying hemipelagic layer has comparatively better sorting and uniform skewness values (Figs. 6).

\subsection{Geochemistry}

The $\mu$-XRF elemental composition of turbidites in core CS- 01 , including $\mathrm{Mn} / \mathrm{Ca}, \mathrm{Fe} / \mathrm{Ca}$,

$\mathrm{K}, \mathrm{Ca}$ and $\mathrm{Sr}$, are presented in Figs. 6,7. Elemental profiles of the turbidite units show similar distinct trends. The most remarkable feature is a sharp increase in $\mathrm{Mn} / \mathrm{Ca}$ at the base of most turbidite units. The positive $\mathrm{Mn} / \mathrm{Ca}$ excursion sometimes extends in the core several centimeters below the base of the turbidite layer (Fig. 6). In the case of amalgamated turbidites, a single $\mathrm{Mn} / \mathrm{Ca}$ peak is generally found somewhere close to the base of turbidite stack (Fig. 7) and multiple $\mathrm{Mn} / \mathrm{Ca}$ anomalies (Fig. 7) rarely occur.

The coarse basal parts of most turbidite units are associated with upward increasing $\mu$ XRF Ca and Sr counts (Figs. 6,7). Basal parts of some turbidite units are commonly depleted in $\mathrm{K}$ compared to the homogenite parts and background sediments due to lower clay (illite) content and higher carbonate content (i.e., the carbonate dilution effect) (Figs. 6,7). The transition from the basal coarse part to the homogenite part of some turbidites is marked by abrupt increases in $\mathrm{K}$ and $\mathrm{Fe} / \mathrm{Ca}$ and a sharp decrease in $\mathrm{Ca}$ and $\mathrm{Sr}$. Since geochemical composition is mostly related to the sediment source, rather than the depositional process, the difference between homogenite and background sediments could not be determined on the basis of $\mu$-XRF elemental changes. 
270

271

272

273

274

275

276

277

278

279

\section{Discussion}

\subsection{Triggering, deposition and sediment sources of turbidites}

As it has been previously pointed out by many authors, there can be different triggering mechanisms for mass-transport deposits including turbidites. These include seismic shaking, storm waves, hyperpycnal flows, gas hydrate dissociation, sediment overloading, volcanic eruptions and floods (Postma et al., 1988; Mulder and Syvitski, 1995; Beck et al., 1996; Shiki et al., 2000; Goldfinger et al., 2003; Schnellmann et al., 2005). Hence, establishment of sedimentological and geochemical criteria for distinguishing turbidites of seismic origin from other origins has been an important objective of numerous studies.

The most plausible triggering mechanism for turbidites in the Kumburgaz Basin is seismic shaking related to the NNAF, which is known to have produced $\mathrm{M}>7$ earthquakes with ca. 150-250 yrs reoccurrence time (Ambraseys and Finkel, 1991, 1995; Guidoboni et al., 1994; Hubert Ferrari et al., 2000; Ambraseys, 2002). Other possible triggering mechanisms such as storm waves, sediment loading and hyperpycnal flows can be discounted for the Kumburgaz Basin for the duration of the core's record (i.e., the last $6.1 \mathrm{kyrs}$ ). There is no major river input on the shelf surrounding the Kumburgaz Basin, with the middle Holocene sea level stand reached already ca. 6.5 kyrs BP (Fairbanks, 1989) and the shelf edge located at ca. $100 \mathrm{~m}$ water depth was 7-8 km away from the coastline. Therefore, sediment loading and hyperpycnal flows are unlikely to be a causal mechanism for triggering the mass-flow events observed in this basin. With the storm wave height less than $10 \mathrm{~m}$ and storm base level less than $30 \mathrm{~m}$ in the SoM (Özhan and Abdallah, 1999), storm waves are also unlikely to be a cause of mass-wasting events on the shelf edge and slopes of the Kumburgaz Basin.

Gas hydrate dissociation as a consequence of warming during Holocene is a plausible mechanism of mass-wasting in the SoM, considering the gas hydrates discovered on the 
Western High and widespread gas emissions from the active faults in the SoM (Halbach et al., 2002; Armijo et al., 2005; Géli et al., 2008; Zitter et al., 2008, 2012; Bourry et al., 2009; Ruffine

et al., 2017). However, observations of gas escape and its past manifestations as carbonate crusts are scarce in the Kumburgaz Basin (Geli et al., 2008; Dupré et al., 2015; Çăgatay et al., 2017), hence gas escape from sediments is a low possibility for causing turbidity currents. The two-fold division of the turbidites into a coarse basal part and a homogenite part observed in the Kumburgaz Basin is taken to be indicative of seismic triggering and associated tsunami events in the SoM and in some lakes (Beck et al., 1996, 2007; Chapron et al., 1999; Çağatay et al., 2012; McHugh et al., 2014). As a result, we consider earthquake shaking to be the most plausible mechanism to trigger turbidity currents from the shelf edge and slope to the Kumburgaz Basin. This conclusion is supported by specific sedimentary structures and depositional characteristics of the turbidites discussed below and their correlation with the historical earthquakes presented in section 6.3.

Geochemical and physical proxies of seismoturbidite units in CS-01 compare well with those in the other basins of the SoM (Sarı and Çağatay, 2006; McHugh et al., 2006, 2014; Beck et al., 2007; Çağatay et al., 2012; Eriş et al., 2012). The Mn/Ca anomalies near the base of the turbidites represent diagenetic enrichment at the oxic/anoxic interface of the sediments in a basin where the bottom waters are oxic (e.g., Çağatay et al., 2004, 2012) (Figs. 6,7). This boundary is presently located at ca. $10 \mathrm{~cm}$ below seafloor in the deep basins of the SoM (Çağatay et al., 2004) but was most likely shallower and closer to the sea floor during the sapropel depositional events during 12.3-5.7 and 5.4-2.7 cal. kyrs BP (Çağatay et al., 2015) in the SoM. The oxic/anoxic interface migrates continuously upward during slow deposition of "background" hemipelagic sediments but the deposition of a new turbidite unit causes the formation of a new redox front further up in the sequence while the older front will stop migrating, leaving a $\mathrm{Mn}$ anomaly at its final location. The elevated $\mathrm{Ca}$ and $\mathrm{Sr}$ contents in the 
sandy basal part of the seismoturbidites are further enhanced in their uppermost parts (Figs. 6,7). Such enrichment is attributed to high amounts of shell material transported from the shelf and upper slope areas. The shell concentration at the top of the coarse basal part occurs because of late deposition due to the platy shape of the biogenic carbonate particles (Figs. 6,7). The presence of ammonia sp., quinqueloculina sp., uvigerina sp. and elphidium sp. in the upper part of the coarse basal layer strongly indicates infralittoral and upper circalittoral depositional settings on the shelf and upper slope areas (Van Morkhoven et al., 1986; Sarı and Çağatay, 2006). The same faunal assemblage characterizes the homogenite parts of the seismoturbidites, whereas the hemipelagic part is almost dominated by bulimina $\mathrm{sp}$. and bolivina sp. This finding strongly indicates the difference in origin of sediments between the homogenite and the overlaying hemipelagic layers.

Grain-size analysis (i.e. ratio of sand, silt, clay) of the seismoturbidite units together with visual observations indicate poorer sorting values (Fig. 6) which have been proposed as the most significant feature for seismoturbidites (Shiki et al., 2000; Arnaud et al., 2002; Goldfinger et al., 2003; Schnellmann et al., 2005; Beck et al., 2007; Carrillo et al., 2008). Sorting parameter together with gamma density could explain the different depositional processes and related settings between the homogenite and hemipelagic sediments (Fig. 6). Considering the deposition of seismoturbidite as a result of earthquakes, settling of the homogenite layer must be instantaneous compared to the hemipelagic sediments, thus, the resulting grain size fractions would have formed relatively more poorly sorted sediments. This likely explains higher density values of homogenites within the turbidite sequence in the Kumburgaz Basin (Fig. 6). Moreover, the positive skewness within the same layer reveals that the homogenite is coarser than the background sediments in Kumburgaz Basin (Fig. 6).

Another important feature of seismoturbidites in confined basins is the multiple sand laminae commonly observed in the upper part of the coarse basal unit. Such a feature is the 
result of long lasting water-column oscillations or "seiche" (Nakajima and Kanai, 2000; Shiki et al., 2000; Sarı and Çağatay, 2006; Beck et al., 2007; Çağatay et al. 2012; Eriş et al., 2012;

Drab et al., 2012; McHugh et al., 2014; Polonia et al 2017). Polonia et al. (2017) suggests a different model for effects of water oscillations on gravity flows. They suggest that oscillations caused by earthquakes in the Ionian Sea created secondary dilute turbidity currents that deposited sediments overlaying the homogenite. Furthermore, they suggest triggering of waveinduced bottom currents that are also caused by the seiche effect. Based on the intensity of the earthquake, distance between hypocenter and basin, and size of the water mass, internal seiche can occur on the basin floor. Hence, the highly fluctuating grain size within the laminated part could be generally regarded as due to oscillatory currents following an earthquake or large landslide, although the hydrodynamic processes by which these oscillatory currents are generated may depend on the case. Similarly, the laminated texture of the seismoturbidites in the Kumburgaz Basin is most likely produced from the "to and fro" oscillating bottom currents after earthquakes (Figs. 6,7).

Such an oscillatory mechanism in the Kumburgaz Basin may also be responsible for a segregation of the bed load from the suspended load, sharpening the boundary between coarse and fine-grained layers. The overlying finer part consists of silt and silt-clay size fractions, where the transition zone is between the basal flow and the suspended cloud, was intensely affected by seiche oscillations resulted in formation of multiple laminations (Figs. 6,7). A similar depositional process was previously described by Beck et al. (2009) for Lake Annecy in France, which is a much smaller basin compared to the Kumburgaz Basin. The "homogenite" part overlying the coarse basal part in core CS-01 represents the mud deposited from the suspended load derived from the outer shelf and slope, and the basinal sediments re-suspended from the Kumburgaz Basin floor (Figs. 1, 2). The relatively uniform elemental composition as inferred from XRF analysis support this conclusion. The lack of vertical changes in texture and 
369 chemical composition implies deep horizontal spreading, similar to any hyperpycnal 370 depositional process in deep marine basins (Mulder et al., 1994; Mulder and Cochonat, 1996;

371

Bouma, 2000).

Apart from the overall physical and geochemical data discussed for the seismoturbidites above, the coarse-grained lower parts, represent a coarse-tail, graded unit that is indicative of low shear stress during a period of rapid sediment fall-out as a traction carpet formed at the base of a turbulent suspension. The general normal grading texture in the seismoturbidite layer is attributed to the waning phase of the turbidite flow (Fig. 6) (Bouma, 1962; Lowe, 1979), when the energy of flow drops gradually. Whereas, grainsize grading is disturbed by fluctuations based on the grainsize parameters (Figs. 6,7). This can be explained by existence of seiche effect during or just after the earthquake, giving rise to strong segregation on suspended particles. This kind of water column oscillations might have produced poorer sorted homogenite in contrast to finer part of a classical turbidite sequence (e.g., division E; Bouma, 1962). Moreover, the only significant sedimentary structure in the basal part of the seismoturbidite is a parallel lamination that is mostly associated with a silt dominated layer. Apart from the lamination (Figs. 6,7), the lack of other internal structures defining a classical Bouma turbidite sequence (Bouma, 1962; Lowe, 1979,1982; Shanmugam, 1997) could be the most remarkable texture of seismoturbidites in the Kumburgaz Basin.

The thickness of the Kumburgaz Basin seismoturbidites range between $2 \mathrm{~cm}$ and $25 \mathrm{~cm}$ (including homogenite part) (Figs. 6,7), which are commonly thinner than those reported from the Tekirdağ, Central and Çınarcık basins (McHugh et al., 2006, 2014; Beck et al., 2007; Çağatay et al, 2012; Eriş et al., 2012; Drab et al., 2012, 2015). This difference is likely the result of several factors including the size of the basin, size of the drainage area, paleoclimate, sea level, size of slope failure and the distance between the depositional basin and epicentral area. During high-stand condition in the SoM after initial flooding of the shelves at 12.5 cal. kyrs 
$\mathrm{BP}$, the warm period would have decreased the stream power to generate low river sediment input on the shelves (Çağatay et al., 2009; Eriş et al., 2012). Several authors also note that mass transport processes and turbidity currents were more frequent and the turbidites were thicker during the lacustrine stage than during the marine episode (Beck et al., 2007, 2014; McHugh et al., 2008; Eriş et al., 2012). The seismoturbidites in core CS-01 were deposited during the high sea level stand. They have similar elemental profiles (e.g., K, Fe/Ca, Ca, Sr) (Figs. 6,7), suggesting a uniform source of the clastic fractions derived from a catchment area with relatively uniform lithology, mainly the Oligocene deltaic sandstones and siltstones (Görür and Okay, 1996; Okay et al., 2000; Adatepe et al., 2002).

We have identified 28 seismoturbidite units in the Kumburgaz Basin over the last 6.1 cal kyrs BP. This number is similar to that observed from the Central Basin depocenter (21 event in the last 5 cal. kyrs BP; McHugh et al., 2014), but more than those observed in the Çınarcık Basin (Beck et al., 2007; Eriş et al., 2012). Such inconsistency in the quantity of seismic events obtained from those basins is most probably due to the proximity of the basin to the earthquake epicenter (Fig. 1). Other factors include, susceptibility of the slopes to mass wasting, sediment storage on the shelf and slopes, and the presence of submarine canyon feeder system in the basin (Fig. 2).

\subsection{Amalgamated Turbidites}

Some seismoturbidites in the Kumburgaz Basin are stacked on top of each other and as such display the features of amalgamated turbidites (Nelson et al., 2012; Gutiérrez-Pastor et al., 2013; Polonia et al., 2017) (Fig. 7). In such amalgamated turbidites, several fining upward layers indicate multiple episodes of traction and deposition of mass-transport material originating from various slope failures and transported via different submarine channels. Some members of the amalgamated seismoturbidite sequences were likely triggered by the same earthquake event rupturing the basin. However, in other seemingly amalgamated 
seismoturbidites, each coarser basal part is associated with a $\mathrm{Mn} / \mathrm{Ca}$-anomaly, indicating a time gap between the two events that allowed the development of new $\mathrm{Mn} / \mathrm{Ca}$-anomaly after the previous event (e.g., ST-6, Fig. 7).

According to Polonia et al. (2017), earthquake-triggered gravity flows originating from multiple sources may form amalgamated structures as stacked turbidite packages (Fig. 7). Therefore, an amalgamation of seismoturbidites in the Kumburgaz Basin may have produced stacked coarse layers without homogenite, since multiple gravity flows during a single earthquake would not have allowed the deposition of the suspended particle cloud, that forms the homogenite on the basin floor. Presence of amalgamated turbidites is detected on the core. In ST-7 (Fig.7), three turbidite deposits capped with a homogenite layer suggest that these turbidites might be the result of subsequent slope failures during a single earthquake, as previously proposed for the Çınarcık Basin (Fig. 7) (Sarı and Çağatay 2006; Eriş et al., 2012;

Drab et al., 2012).

The stacked layers within amalgamated unit are compositionally similar in coarse fraction which suggests multiple slides from the same sources. This is supported by similar trends in some elemental profiles $(\mathrm{Fe} / \mathrm{Ca}, \mathrm{Ca}$ and $\mathrm{Sr}$ ) through the seismoturbidite layers (Fig. 7). The catchment areas of the two main feeder canyons on the northern shelf (NC and NEC; Figs. 1,2) are characterized by similar lithological composition (erosion products of Oligocene siliciclastic rocks; Görür and Okay, 1996; Okay et al., 2000; Adatepe et al., 2002), so it is not possible to distinguish the source of any particular seismoturbidite. It is possible that the observed seismoturbidite results from a unique major mass wasting event, or from the gathering of several slumps turning into coeval turbidites and channelized within three main canyons around the basin (Fig. 2).

\subsection{Correlation of the turbidites with historical earthquakes and late Holocene}

\section{Earthquake records from Kumburgaz Basin}


According to the age-depth model, core CS-01 covers a period between ca. $\sim 813$ cal. a. BP and $\sim 6116$ cal. a. BP (Fig. 5), and includes 28 seismoturbidite (ST) units interrupting the marine hemipelagic sequence. The most recent important historical earthquakes (i.e.; AD 1766, 1509 and 1343) were not detected in this core, since the top $2.5 \mathrm{~m}$ was not recovered. Nine of the seismoturbidites are within the $\sim 2300$ years-long historical period for which earthquake records are available in the published historical catalogues (e.g., Ambraseys and Finkel, 1991, 1995; Guidoboni et al., 1994, 2005; Ambraseys, 2002; Altınok et al 2011; Tables 2,3). Although the age range of some of the seismoturbidites correspond to more than one historical earthquake, we chose to select the relatively large magnitude earthquake within the age-model interval, with the epicenters closest to the Kumburgaz Basin (Fig. 5, Tables 2,3). It is important to note that historical earthquake catalogs can be incomplete in terms of several factors (i.e.; population, local intensity of the earthquake, political circumstances, wars, distraction from other natural disasters) usually affecting the records of the chronologists. Hence, we chose to rely on earthquakes that are documented in several historical catalogs.

ST-1 is dated between $1077 \mathrm{AD}-817 \mathrm{AD}$ (mean age is $964 \mathrm{AD}$ ), and may be correlated to a number of earthquakes that occurred during this interval; $1063 \mathrm{AD}, 1010 \mathrm{AD}$, $989 \mathrm{AD}, 862 \mathrm{AD}$ are all documented in the catalogues as earthquakes affecting Constantinople (İstanbul) region (Ambraseys and Finkel, 1991; Ambraseys, 2002; Guidoboni et al., 2005). However, the $989 \mathrm{AD}(7.2 \mathrm{Ms})$ and the $1010 \mathrm{AD}$ (7.0 Ms) earthquakes are described to cause more significant destruction to Constantinople compared to the other earthquakes listed above and better mesh with the mean age of the ST-1. Guidoboni et al. (2005) mention that the buildings including several churches and specifically the Churches of Forty Martyrs and All Saints in Constantinople was damaged by the earthquake shocks of the 1010 AD. Records mention about aftershocks lasting for forty days following the main event. The 989 AD earthquake was reported to cause a larger scale destruction in Constantinople where houses, the 
city walls and western side of the St. Sophia collapsed. Guidoboni et al. (1994) describe systematic aftershocks following the 989 AD earthquake. This earthquake set up waves in the sea between the provinces of Thrace to İstanbul described as tsunami waves in Altinok et al. (2011). Based on the destruction intensity reported in the historical records and the thickness of the ST-1 (the thickest in CS-01; 50 cm), the 989 AD earthquake is the most likely event that can be correlated with this seismoturbidite unit. Sedimentary records related to the 989 AD earthquake are also documented in the Çınarcık Basin (Drab et al., 2015) (Table 3).

ST-2, with a calibrated age of 975 AD - 640 AD (mean: 820 AD), can be correlated with the $989 \mathrm{AD}, 869 \mathrm{AD}, 862 \mathrm{AD}, 796 \mathrm{AD}$ earthquakes which affected Constantinople (İstanbul) and its surrounding areas (Guidoboni et al., 1994; Ambraseys, 2002). Historical reports describe severe damages and fatalities in Constantinople during the $862 \mathrm{AD}$ and the 869 $\mathrm{AD}$ earthquakes. The $869 \mathrm{AD}$ was mentioned as an earthquake that lasted for forty days and forty nights (most probably aftershocks lasting 40 days); many churches collapsed including the St. Mary, killing many people inside it (Guidoboni et al., 1994). The 862 AD earthquake was reported to cause series of strong ground shakings bringing down the city walls of Constantinople. Statue of Victory at the Golden Gate and church of St.Anne collapsed during this earthquake (Guidoboni et al., 1994). The 862 and 869 AD earthquakes better fall in the range of the mean age of the ST-2 and most likely represent the closest epicenters to İstanbul based on the damages caused among the other earthquakes listed above.

ST-3 is within the age range of $963 \mathrm{AD}-608 \mathrm{AD}$ (mean: 796 AD). Within this interval, it may correspond to the $869 \mathrm{AD}, 862 \mathrm{AD}, 849-851 \mathrm{AD}, 796 \mathrm{AD}, 740 \mathrm{AD}$ earthquakes, all documented within the Constantinople region (Ambraseys and Finkel, 1991; Ambraseys, 2002; Guidoboni et al., 2005). and one of the 869 AD and 862 AD earthquakes are most likely associated with the deposition of ST-2 thus we seek to understand the details of other events that are listed here. The $849-851 \mathrm{AD}$ is mentioned as a moderate earthquake in the catalogues 
and the $796 \mathrm{AD}$ is reported with very few details. The largest earthquake within the age range of ST-3 is the 740 AD event with Ms=7.1 and I=IX-XI (Guidoboni et al., 1994; Ambraseys, 2002; Altinok et al., 2011). Large scale destruction in İstanbul, İzmit and its surroundings, and a tsunami affecting the coastal areas of İzmit, were reported (Altinok et al., 2011). The aftershocks of this earthquake lasted almost a year (Guidoboni et al., 1994). The 740 AD may have caused the deposition of ST-3 also taking into account the good fit with mean age of ST3. This event has also been observed as a distinct seismoturbidite unit in the sedimentary sequences of most SoM basins (McHugh et al., 2006; Çağatay et al., 2012; Drab et al., 2015) (Table 3).

ST-4 gives a wider age interval between $907 \mathrm{AD}-357 \mathrm{AD}$ (mean age: $\sim 658 \mathrm{AD}$ ) based on the age-depth model thus it may coincide with long list of historical earthquakes affected Constantinople region (862 AD, 796 AD, 740 AD, 557 AD, 554 AD, and 478-480 AD) (Guidoboni et al., 1994; Ambraseys, 2002). It is rather difficult to make a more precise correlation from the historical events within a $\sim 600$ age interval. Therefore, we chose to select events that fits better with the mean age of the ST-4 and neglect the ones already discussed for the previous seismoturbidite records. There are two major earthquakes (557 AD and $554 \mathrm{AD}$ ) in the region that may correspond to the deposition of ST-4. The $557 \mathrm{AD}$ event is described in detail in many historical records as a terrible and devastating earthquake destructing many churches, houses, the city walls and killing many people in Constantinople (Guidoboni et al., 1994). Tremors felt for ten days and a tsunami was reported (Altinok et al., 2011). A wide region including Nicomedia (İzmit) and Nicea (İznik) were affected from this earthquake (Guidoboni et al., 1994). The 554 AD earthquake was felt in Constantinople (İstanbul) where houses, churches and part of the walls of Constantinople were damaged or collapsed during this earthquake (Ambraseys and Finkel, 1991; Guidoboni et al., 1994). ST-4 may correspond to either the $554 \mathrm{AD}$ or the $557 \mathrm{AD}$ earthquakes. However, the $557 \mathrm{AD}$ is documented as a larger 
earthquake and may be a closer epicenter to İstanbul. Sedimentary records of the $557 \mathrm{AD}$ earthquake were also documented in the Central Basin (McHugh et al., 2014) (Table 3).

ST-5 is dated between $858 \mathrm{AD}-233 \mathrm{AD}$ (mean age: $578 \mathrm{AD}$ ) within the age-depth model. The $740 \mathrm{AD}, 557 \mathrm{AD}, 554 \mathrm{AD}, 542 \mathrm{AD}, 478 \mathrm{AD}, 447 \mathrm{AD}$ earthquakes all fall into the 550 age interval (Ambraseys and Finkel, 1991; Guidoboni et al., 1994; Ambraseys, 2002). The $478 \mathrm{AD}$ and the $447 \mathrm{AD}$ (both events are considered as I: IX) are mentioned as major earthquakes that damaged Constantinople and the Marmara region in several catalogues (Ambraseys and Finkel, 1991; Guidoboni et al 1994; Ambraseys, 2002; Altinok et al., 2011) and Altınok et al. (2011) suggest occurrence of tsunami waves after these earthquakes. The 542 AD is reported with less detail in Guidoboni et al. (1994), thus either of the 478 AD and the $447 \mathrm{AD}$ earthquakes may be the likely matches of the ST-5. There are sedimentary records also dated corresponding to the $478 \mathrm{AD}$ earthquake in Çınarcık Basin (Drab et al., 2015) (Table 3). ST-6 has an age range between 746 AD - 169 AD (mean: 464 AD). The earthquakes documented in Constantinople region within this interval covers the $740 \mathrm{AD}, 557 \mathrm{AD}, 554 \mathrm{AD}$, 478 AD, 447 AD, 437 AD, 407 AD, 358 AD earthquakes (Guidoboni et al 1994; Ambraseys and Finkel, 1991; Ambraseys, 2002). The 437 AD earthquake was described as a great earthquake lasting for four months; this event was reported from one reliable source in the history (Guidoboni et al 1994). The 407 AD earthquake destroyed many houses, caused damage and casualties in Constantinople particularly in the coastal districts. Sea waves are reported on the shores wrecking many ships (Ambraseys and Finkel, 1991). The Ottoman archives confirm that many ships sunk because of a tsunami caused by an earthquake (Altinok et al., 2011). There are several reports on the destructiveness of the $407 \mathrm{AD}$ earthquake thus it is most likely that it may correspond to ST-6. Although the 358 AD event affected Constantinople, the majority of the damage was reported in the city of Nicomedia (İzmit) and 
Nicea (İznik). Sedimentary records are documented the 358 AD earthquake in Gulf of İzmit (Çağatay et al., 2012) (Table 3) supports the distance of this event from Istanbul.

ST-7 has an age range of 328 AD-43 BC (mean. 135 AD). Few chronologically accurate events can be found in the historical catalogues within this time interval (the 180-181 $\mathrm{AD}$ and the 120-128 AD earthquakes). The 180-181 AD earthquake was mentioned as the third catastrophe for Nicomedia (İzmit) describing a very destructive earthquake (Guidoboni et al., 1994; Ambraseys, 2002). Records mention that the Emperor requested support for reconstruction of the damaged regions (Guidoboni et al., 1994; Ambraseys, 2002). Another major earthquake reported to destroy the greater part of Nicomedia (İzmit) together with their respective districts in the120-128 AD. The 120-128 AD and the 180-181 AD earthquakes are in agreement with the mean age value of ST-7 and can most likely be associated with this sedimentary record. Sedimentary traces of 180-181 AD earthquake are also dated in other cores from the Gulf of İzmit (McHugh et al., 2006) (Table 3).

The age of ST-8 ranges between $88 \mathrm{AD}-206 \mathrm{BC}$ (mean: $63 \mathrm{BC}$ ) and may be associated with the $69 \mathrm{AD}$ and the $29 \mathrm{AD}$ earthquakes documented in Constantinople and surrounding regions (Guidoboni et al 1994; Ambraseys, 2002). The 29 AD and the 69 AD earthquakes are described as damaging the Nicea (İznik) and the Nicomedia (İzmit) regions, respectively, which were the two major settlements in eastern Marmara (Bithynia) at that period. Therefore, one of those can be responsible for the deposition of ST-8.

ST-9 has an age range of $119 \mathrm{BC}-458 \mathrm{BC}$ (mean: $284 \mathrm{BC}$ ). The $427 \mathrm{BC}$ earthquake described in the ancient catalogues damaging the city Perinthos (Marmara Ereğlisi), which was the main settlement at the time (Guidoboni et al., 1994). The 287 BC occurred in Lysimachia (around Şarköy) and mostly damaged Hellespont area (Dardanelles). It is difficult to match these events precisely with ST-9 since there were no major settlement in İstanbul at that time. Therefore, from this point forward the historical records provide limited information in terms 
of damage intensities corresponding to wider areas. Either of the $287 \mathrm{BC}$ and the $427 \mathrm{BC}$ can be correlated with ST-9.

The remaining 19 seismoturbidites have mean values based on the age-depth model (Table 2,

Fig. 5). Sedimentary section from CS-01 provide records of 28 seismoturbidite units within the last $\sim 6116$ yrs suggest an average recurrence time interval of. $\sim 220$ yrs. The interval between consecutive events ranges between 40 yrs to 425 yrs in Kumburgaz Basin. The average earthquake recurrence interval derived from CS-01 core from Kumburgaz Basin is compatible with the recurrence interval of 150-250 yrs of the NNAF based on historical records (Ambraseys and Finkel, 1991, 1995; Guidoboni et al., 1994, 2005; Ambraseys and Jackson, 2000; Ambraseys, 2002) and the geodetic and seismological studies (Reilinger, 1997, Straub et al., 1997, McClusky et al., 2000; Flerit et al., 2003; Pondard et al., 2007; Reilinger et al., 2006). The recent well known earthquake sequence of the 1999 AD, 1912 AD, 1894 AD, May 1766 AD, August 1766 AD, 1719 AD, 1754 AD and 1509 AD (M>7) earthquakes are produced by the rupture of submerged segments of the NNAF (Fig.1) in the SoM (Ambraseys, 2001,2002; Barka et al., 2002; Parsons, 2004; Armijo et al., 2005; Pondard et al., 2007; Uçarkuş et al., 2011; McHugh et al., 2014), highlighting the consecutive earthquake cycle for the last $500 \mathrm{yrs}$ and supporting the recurrence time interval of 150-250 yrs.

\section{Conclusion}

Basins of the SoM acts as recorders of sediment input fluctuations due to tectonic activity of the North Anatolian Fault. Thus, the study of seismoturbidite sequences is a critical tool to evaluate earthquake recurrence intervals on such a seismically active fault zone. Our multiparameter study on a piston core (Core MRS-CS-01) from Kumburgaz Basin, is the first high resolution sedimentological and geochemical study revealing the seismoturbidites deposited over the last $\sim 6.1$ kyrs for this basin. Core MRS-CS-01 includes 28 turbidite units that are intercalated with hemipelagic sediments. Turbidite-Homogenite units are characterized by a 
coarse laminated sandy-silty basal part, overlaid by a seiche controlled laminated part and a homogeneous mud (homogenite) cap. Based on the geochemical, physical and textural proxies together with ${ }^{14} \mathrm{C}$ dating, the most probable trigger is inferred to be earthquakes. Indications of earthquake triggering comprise deposition of thinly laminated deposits caused by oscillatory currents and deposition from multiple gravity flow deposits (amalgamated turbidites) triggered by the same or by subsequent events.

All 28 seismoturbidite units show similar detrital markers. Coarse laminated sand-silty basal parts show high magnetic susceptibility and gamma density values due to accumulation of the detrital elements (High $\mathrm{Fe} / \mathrm{Ca}$ and $\mathrm{K}$, low $\mathrm{Ca}$ and $\mathrm{Sr}$ content). Oscillations of current intensity, presumably related to seiche effects, caused the deposition of thin laminations that result in rapidly varying elemental compositions. Laminations are capped with a $\mathrm{Ca}$ and $\mathrm{Sr}$ increase which is caused by the accumulation of biogenic fragments at the top of the turbidite. The homogenite layer results from the deposition of the fine particle cloud sent in suspension by the gravity currents, and is dominated by the clay fraction (High $\mathrm{K}$ ) with a gradually decreasing gamma density at its top. $\mathrm{Mn} / \mathrm{Ca}$ anomalies are another important indicator, which is detected as one or several positive spikes at the base of the seismoturbidites. These $\mathrm{Mn} / \mathrm{Ca}$ anomalies are interpreted as fossil redox fronts. Based on the multi-parameter analyses, we conclude that the seismoturbidites of the Kumburgaz basin differ from the typical turbidite description (e.g. Bouma sequence) and also presents some differences from turbidites of the other basins of SoM.

The seismoturbidite records from core CS-01 provide an average recurrence time interval of $\sim 220 \mathrm{yrs}$ for the last $6.1 \mathrm{kyrs}$ which is in agreement with geodetic, seismological studies and historical earthquake records from the SoM. 9 out of 28 seismoturbidites from CS-01 can be associated with historical earthquakes reported in the last two millennia. These frequent longterm sedimentary traces (28 ST unit in $\sim 6$ kyrs) found in CS-01 suggest that the Kumburgaz Basin has been recording earthquakes as much as other deeper basins along the NNAF in the 
618 SoM. The most recent part of the sedimentary record (ca. 1200 yrs to present) is missing from 619 this core, thus it is still not known whether the $1766 \mathrm{AD}$, the 1509 AD or the $1343 \mathrm{AD}$ 620 earthquakes were related to Central High Segment or not. Further core recovery and sediment 621 analysis are crucial to enlighten the correspondence of recent large earthquakes with this 622 segment to make a more precise seismic hazard assessment for İstanbul.

\section{Acknowledgements}

624 Cores were taken during MARSITECRUISE of Ifremer/Genavir R.V. Pourquoi Pas ?, within 625 the framework of MARSITE FP7 EU Project (Grant Agreement no.: 308417). Radiocarbon 626 dating was performed at ARTEMIS (French national radiocarbon dating facility) and funded 627 by INSU post-cruise research support program. Part of this work has been supported by 628 Bilateral ANR/TÜBITAK collaborative research project MAREGAMI (ANR-16-CE03-001062902 and Tubitak Project (116Y371). Apart of this work has been supported by ITU BAP project 630 (39273). All geochemical and sedimentological analyses were performed in ITU EMCOL laboratories. We wish to thank Dursun Acar for his support during the analyses, Edouard Bard and Bora Ön for their help and advice on age model construction. 
634

635

636

637

638

639

640

641

642

643

644

645

646

647

648

649

650

651

652

653

654

655

656

657

658

659

\section{References}

Adams, J., 1990. Paleoseismicity of the Cascadia subduction zone: Evidence from turbidites off the Oregon-Washington margin. Tectonics, 9(4), 569-583.

Aksu, A. E., Hiscott, R. N., \& Yaşar, D., 1999. Oscillating Quaternary water levels of the Marmara Sea and vigorous outflow into the Aegean Sea from the Marmara Sea-Black Sea drainage corridor. Marine Geology, 153(1-4), 275-302.

Altinok, Y., Alpar, B., Özer, N., \& Aykurt, H., 2011. Revision of the tsunami catalogue affecting Turkish coasts and surrounding regions. Natural Hazards and Earth System Sciences, 11(2), 273.

Ambraseys, N.N., Finkel, C.F., 1991. Long term seismicity of the Istanbul and of the Marmara Sea region. Terra Nova 3, 527-539.

Ambraseys, N.N., Finkel, C.F., 1995. The Seismicity of Turkey and Adjacent Areas-A Historical Review. Eren Yayınc1lı, Istanbul, pp. 1500-1800. 240 pp.

Ambraseys, N.N., Jackson, J.A., 2000. Seismicity of Sea of Marmara (Turkey) since 1500. Geophysics Journal International 141, F1-F6.

Ambraseys, N. N. 2001. The earthquake of 1509 in the Sea of Marmara, Turkey, revisited. Bulletin of the Seismological Society of America, 91(6), 1397-1416.

Ambraseys, N.N., 2002. The seismic activity of the Marmara Sea region over the last 2000 years. Bulletin of the Seismological Society of America 92, 1-18.

Armijo, R., Meyer, B., Navarro, S., King, G., Barka, A., 2002. Asymmetric slip partitioning in the Sea of Marmara pull-apart: a clue to propagation processes of the North Anatolian Fault. Terra Nova 14 (2), 80-86.

Armijo, R., Pondard, N., Meyer, B., Mercier de Lapinay, B., Ucarkus, G., the MARMARASCARPS Cruise Party, 2005. Submarine fault scarps in the Sea of Marmara pullapart (North Anatolian Fault): implications for seismic hazard in Istanbul. Geochemistry, Geophysics, Geosystems 6, 1-29. 
660 Arnaud, F., Lignier, V., Revel, M., Desmet, M., Beck, C., Pourchet, M., Charlet, F., Trentesaux, 661 A., Tribovillard, N., 2002. Flood and earthquake disturbance of 210Pb geochronology (Lake 662 Anterne, NW Alps). Terra Nova 14, 225-232.

663 Avşar, U., Hubert-Ferrari, A., De Batist, M., Schmidt, S., \& Fagel, N., 2015. Sedimentary 664 records of past earthquakes in Boraboy Lake during the last ca 600 years (North Anatolian 665 Fault, Turkey). Palaeogeography, Palaeoclimatology, Palaeoecology, 433, 1-9.

666 Barka, A., Akyuz, H. S., Altunel, E., Sunal, G., Cakir, Z., Dikbas, A., ... \& Rockwell, T. 2002. 667 The surface rupture and slip distribution of the 17 August 1999 Izmit earthquake (M 7.4), North 668 Anatolian fault. Bulletin of the Seismological Society of America, 92(1), 43-60.

669 Barnes, P. M., Bostock, H. C., Neil, H. L., Strachan, L. J., \& Gosling, M. 2013. A 2300-Year 670 Paleoearthquake Record of the Southern Alpine Fault and Fiordland Subduction Zone, New 671 Zealand, Based on Stacked Turbidites. Bulletin of the Seismological Society of America, 672 103(4), 2424-2446.

673 Beck, C., Manalt, F., Chapron, E., Van Rensbergen, P., De Batist, M., 1996. Enhanced 674 seismicity in the early post-glacial period: evidence from the post-würm sediments of Lake 675 Annecy, Northwestern Alps. Journal of Geodynamics 22, 155-171.

676 Beck, C., Mercier de Lapinay, B., Schneider, J.L., Cremer, M., Cagatay, N., Wendenbaum, E., 677 Boutareaoud, S., Menot, G., Schmidt, S., Webe, O., Eris, K., Armijo, R., Meyer, B., Pondard, 678 N., Gutcher, M.A., Turon, J.L., Labeyrie, L., Cortijo, E., Gallet, Y., Bouquerel, H., Gorur, N., 679 Geravis, A., Castera, M.H., Londeix, L., de Resseguier, A., Jaouen, A., 2007. Late Quaternary 680 co-seismic sedimentation in the Sea of Marmara's deep basins. Sedimentary Geology 199, 6568189.

682 Beck, C., 2009. Late Quaternary lacustrine paleo-seismic archives in north-western Alps: 683 examples of earthquake-origin assessment of sedimentary disturbances. Earth Science Review $68496,327-344$.

685 Beşiktepe, Ş. T., Sur, H. I., Özsoy, E., Latif, M. A., Oğuz, T., \& Ünlüata, Ü., 1994. The 686 circulation and hydrography of the Marmara Sea. Progress in Oceanography, 34(4), 285-334. 
687

688

689

690

691

692

693

694

695

696

697

698

699

700

701

702

703

704

705

706

707

708

709

710

711

712

Bouma A. H., 1964. Turbidites. In: Bouma AH, Brouwer A (eds) Turbidites. Developments in sedimentology, vol 3. Elsevier, Amsterdam, pp 247-256. doi:10.1016/S0070-4571(08)709671.

Bouma, A. H., 2000. Coarse-grained and fine-grained turbidite systems as end member models: applicability and dangers. Marine and Petroleum Geology, 17(2), 137-143.

Bourry, C., Chazallon, B., Charlou, J. L., Donval, J. P., Ruffine, L., Henry, P., ... \& Moreau, M., 2009. Free gas and gas hydrates from the Sea of Marmara, Turkey: Chemical and structural characterization. Chemical Geology, 264(1-4), 197-206.

Çağatay, N., Görür, N., Algan, O., Eastoe, C. J., Tchapalyga, A., Ongan, D., ... \& Kuscu, I., 2000. Late Glacial-Holocene paleoceanography of the Marmara Sea: timing of connections with the Mediterranean and the Black Seas. Marine Geology, 167, 191-206.

Çağatay, M. N., Borowski, W. S., \& Ternois, Y. G., 2001. Factors affecting the diagenesis of Quaternary sediments at ODP Leg 172 sites in western North Atlantic: evidence from pore water and sediment geochemistry. Chemical Geology, 175(3-4), 467-484.

Çağatay, M. N., Görür, N., Polonia, A., Demirbağ, E., Sakınç, M., Cormier, M. H., ... \& Eriş, K., 2003. Sea-level changes and depositional environments in the Izmit Gulf, eastern Marmara Sea, during the late glacial-Holocene period. Marine Geology, 202(3-4), 159-173.

Çağatay, M.N., Özcan, M., Güngör, E., 2004. Pore water and sediment geochemistry in the Marmara Sea (Turkey): early diagenesis and diffusive fluxes. Geochemistry: Exploration, Environment, Analysis 4, 213-225.

Çağatay, M. N., Görür, N., Flecker, R., Sakınç, M., Tünoğlu, C., Ellam, R., ... \& Dikbaş, A., 2006. Paratethyan-Mediterranean connectivity in the Sea of Marmara region (NW Turkey) during the Messinian. Sedimentary Geology, 188, 171-187.

Çağatay, M. N., Eriş, K., Ryan, W. B. F., Sancar, Ü., Polonia, A., Akçer, S., ... \& Bard, E., 2009. Late Pleistocene-Holocene evolution of the northern shelf of the Sea of Marmara. Marine Geology, 265(3-4), 87-100. 
713 Çağatay, M.N., Erel, L., Bellucci, L.G., Polonia, A., Gasperini, L., Eris, K., Sancar, Ü., Biltekin, 714 D., Uçarkus, G., Ülgen, U.B., Damci, E., 2012. Sedimentary earthquake records in the Izmit 715 Gulf, Sea of Marmara, Turkey. Sedimentary Geology 282, 347-359. 716 http://dx.doi.org/10.1016/j.sedgeo.2012.10.001.

717 Çağatay, M. N., Geli, L., Gasperini, L., Henry, P., Gürbüz, C., \& Görür, N., 2015. Seafloor 718 observations and observatory activities in the Sea of Marmara. In SEAFLOOR OBSERVATORIES (pp. 59-79). Springer, Berlin, Heidelberg.

720

721

722

723

724

725

726

727

Çağatay, M. N., Wulf, S., Sancar, Ü., Özmaral, A., Vidal, L., Henry, P., ... \& Gasperini, L., 2015. The tephra record from the Sea of Marmara for the last ca. $70 \mathrm{ka}$ and its palaeoceanographic implications. Marine Geology, 361, 96-110.

Çağatay, M. N., Yıldız, G., Bayon, G., Ruffine, L., \& Henry, P., 2017. Seafloor authigenic carbonate crusts along the submerged part of the North Anatolian Fault in the Sea of Marmara: Mineralogy, geochemistry, textures and genesis. Deep Sea Research Part II: Topical Studies in Oceanography.

Carrillo, E., Beck, C., Audemard, F.A., Moreno, E., Ollarves, R., 2008. Disentangling Late Quaternary climatic and seismo-tectonic controls on Lake Mucubaji sedimentation (Merida Andes, Venezuela). Palaeogeography Palaeoclimatology Palaeoecology 259, 284-300.

Carton, H., 2003. Structure of the Cinarcik Basin (eastern Marmara Sea) from densely-spaced multi-channel reflection profiles. Lithos Science Report.

Chapron, E., Beck, C., Pouchet, M., Deconninck, J.F., 1999. 1822 earthquake-triggered homogenite in Lake Le Bouget (NW Alps). Terra Nova 11, 86-92.

Cita, M.B., Bossio, A., Colombio, A., Gnaccolini, M., Salvatorini, G., Broglia, C., Camerlenghi, A., Catrullo, D., Clauzon, G., Croce, M., Giambastiani, M., Kastens, K.A., Malinverno, A., McKoy, F.W., Parisi, E., 1982. Sedimentation in the Mediterranean Ridge Cleft (DSDP Site 126). Member of Society of Geology, Italy 24, 427-442.

Cita, M.B., Beghi, C., Camerlenghi, A., Kastens, K.A., McKoy, F.W., Nosetto, A., Parisi, E., Scolari, F., Tomadin, L., 1984. Turbidites and megaturbidites from the Herodotus Abyssal Plain (Eastern Mediterranean) unrelated to seismic events. Marine Geology 55, 79-101. 
Cita, M.B., Carmerlenghi, A., Rimoldi, B., 1996. Deep-sea tsunami deposits in the eastern Mediterranean: new evidence and depositional models. Sedimentary Geology 104, 155-173.

Cita, M.B., Aloisi, G., 2000. Deep-sea tsunami deposits triggered by the explosion of Santorini (3500 a BP), Eastern Mediterranean. Sedimentary Geology 135, 181-203.

Drab, L., Hubert-Ferrari, A., Schmidt, S., Martinez, P., 2012. The earthquake record in the western part of the Sea of Marmara, Turkey. In: Pantosi, D. (Ed.), Natural Hazards and Earth System Sciences, Special Issue "Subaqueous Paleoseismology", pp. 1235-1254. http://dx.doi.org/10.5194/nhess-12-2012.

Drab, L., Hubert-Ferrari, A., Schmidt, S., Martinez, P., Carlut, J., \& El Ouahabi, M., 2015. Submarine earthquake history of the Çınarcık segment of the North Anatolian Fault in the Marmara Sea, Turkey. Bulletin of the Seismological Society of America, 105(2A), 622-645.

Ergintav, S., Reilinger, R. E., Çakmak, R., Floyd, M., Cakir, Z., Doğan, U., ... \& Özener, H. 2014. Istanbul's earthquake hot spots: Geodetic constraints on strain accumulation along faults in the Marmara seismic gap. Geophysical Research Letters, 41(16), 5783-5788.

Eriş K.K., Ryan WBF, Çağatay MN, Sancar U, Lericolais G, Ménot G, Bard E., 2008. Reply to comment on "The timing and evolution of the post-glacial transgression across the Sea of Marmara shelf south of İstanbul” by Hiscott et al. Marine Geology 248:228-236

Eriş, K. K., Çağatay, M. N., Akçer, S., Gasperini, L., \& Mart, Y., 2011. Late glacial to Holocene sea-level changes in the Sea of Marmara: new evidence from high-resolution seismics and core studies. Geo-Marine Letters, 31(1), 1-18.

Eriş, K.K., Çağatay, N., Beck, C., Mercier de Lepinay, B., Campos, C., 2012. Late-Pleistocene to Holocene sedimentary fills of the Cinarcik Basin of the Sea of Marmara. Sedimentary Geology 281, 151-165.

Fairbanks, R. G., 1989. A 17,000-year glacio-eustatic sea level record: influence of glacial melting rates on the Younger Dryas event and deep-ocean circulation. Nature, 342(6250), 637. 
766

767

768

769

770

771

772

773

774

775

776

777

778

779

780

781

782

783

784

Flerit, F., Armijo, R., King, G. C. P., Meyer, B., \& Barka, A., 2003. Slip partitioning in the Sea of Marmara pull-apart determined from GPS velocity vectors. Geophysical Journal International, 154(1), 1-7.

Géli, L., Henry, P., Zitter, T., Dupré, S., Tryon, M., Çağatay, M.N., de Lépinay, B., Mercier, Le Pichon, X., Sengör, A.M.C., Görür, N., Natalin, B., Uçarkus, G., Özeren, S., Volker, D., Gasperini, L., Burnard, P., Bourlange, S., the Marnaut Scientific, Party, 2008. Gas emissions and active tectonics within the submerged section of the North Anatolian Fault zone in the Sea of Marmara. Earth and Planetary Science Letters 274 (1-2), 34-39.

Gökaşan, E., Ergin, M., Özyalvaç, M., Sur, H. İ., Tur, H., Görüm, T., ... \& Türker, A., 2008. Factors controlling the morphological evolution of the Çanakkale Strait (Dardanelles, Turkey). Geo-Marine Letters, 28(2), 107-129.

Goldfinger, C., Nelson, C.H., Johnson, J.E., 2003. Holocene earthquake records from the Cascadia subduction zone and northern San Andreas fault based on precise dating of offshore turbidites. Annual Review of Earth and Planetary Sciences 31, 555-577.

Goldfinger, C., Morey, A.E., Nelson, C.H., Gutierrez-Pastor, J., Johnson, J.E., et al., 2007. Rupture lengths and temporal history of significant earthquakes on the offshore and north coast segments of the northern San Andreas Fault based on turbidite stratigraphy. Earth and Planetary Science Letters 254, 9-27.

Goldfinger, C., Grijalva, K., Burgmann, K., Morey, A., Johnson, J.E., Nelson, C.H., GutiérrezPastor, J., Karabanov, E., Patton, J., Gracia, E., 2008. Late Holocene rupture of the northern San Andreas Fault and possible stress linkage to the Cascadia Subduction Zone. Seismological Society of America, Bulletin 98, 861-899.

Goldfinger, C., 2011. Submarine paleoseismology based on turbidite records. Annual Review of Marine Science 3, 35-66.

Goldfinger, C., Galer, S., Beeson, J., Hamilton, T., Black, B., Romsos, C., ... \& Morey, A., 2017. The importance of site selection, sediment supply, and hydrodynamics: A case study of submarine paleoseismology on the Northern Cascadia margin, Washington USA. Marine Geology, 384, 4-46. 
794

795

796

797

798

799

800

801

802

803

804

805

806

807

808

809

810

811

812

813

814

815

816

817

818

819

820

Görür, N., \& Okay, A. I. 1996. A fore-arc origin for the Thrace Basin, NW Turkey. Geologische Rundschau, 85(4), 662-668.

Görür, N., \& Çağatay, M. N., 2010. Geohazards rooted from the northern margin of the Sea of Marmara since the late Pleistocene: a review of recent results. Natural hazards, 54(2), 583-603.

Gracia, E., Vizcaino, A., Escutia, C., Asioi, A., Rodes, A., Pallas, R., Garcia-Orellana, J., Lebreiro, S., Goldfinger, C., 2010. Holocene earthquake records offshore Portugal (SW Iberia): testing turbidite paleoseismology in a slow-convergence margin. Quaternary Science Reviews $29,1156-1172$.

Grall, C., Herny, P., Thomas, Y., Westbrook, G.K., Çağatay, M.N., Marsset, B., Saritas, H., Çifici, G., Geli, L., 2013. Slip rate estimations along the western segment of the Main Marmara Fault over the last 405-490 ka by correlating mas transport deposits. Tectonics 32, 1-15.

Guidoboni, E., Comastri, A., Traina, G., 1994. Catalogue of Ancient Earthquakes in the Mediterranean Area up to 10th Century. INGV-SGA, Bologna. 504 pp.

Guidoboni, E., Comastri, A., 2005. Catalogue of Earthquakes and Tsunamis in the Mediterranean Area from 11th to the 15th Century. INGV-SGA, Bologna. 1057 pp.

Halbach, P., Kuşçu, İ., Inthorn, M., Kuhn, T., Pekdeğer, A., \& Seifert, R., 2002. Methane in sediments of the deep Marmara Sea and its relation to local tectonic structures. In Integration of Earth Science Research on the Turkish and Greek 1999 Earthquakes (pp. 71-85). Springer, Dordrecht.

Hofmann, B. A., 1999. Geochemistry of natural redox fronts-a review. Nagra.

Houghton, P.D.V., 1994. Deposits of deflected or ponded turbidity currents, Sorbas Basin, southeast Spain. Journal of Sedimentary Research A64, 233-246.

Hubert-Ferrari, A., Barka, A., Jacques, E., Nalbant, S. S., Meyer, B., Armijo, R., ... \& King, G. C., 2000. Seismic hazard in the Marmara Sea region following the 17 August 1999 Izmit earthquake. Nature, 404(6775), 269.

Kastens, K., Cita, M.B., 1981. Tsunami-induced sediment transport in the abyssal Mediterranean Sea. Geological Society of America Bulletin 119, 151-165. 
821 Kastens, K.A., 1984. Earthquakes as a triggering mechanism for debris flows and turbidites on the Calabrian Ridge. Marine Geology 55, 13-33.

823

824

Klein, E., Duputel, Z., Masson, F., Yavasoglu, H., \& Agram, P. 2017. Aseismic slip and seismogenic coupling in the Marmara Sea: What can we learn from onland geodesy? Geophysical Research Letters, 44(7), 3100-3108.

Laigle, M., Becel, A., de Voogd, B., Hirn, A., Taymaz, T., \& Ozalaybey, S. 2008. A first deep seismic survey in the Sea of Marmara: Deep basins and whole crust architecture and evolution. Earth and Planetary Science Letters, 270(3-4), 168-179.

Le Pichon, X., Şengör, A.M.C., Demirbağ, E., Rangin, C., Imren, C., Armijo, R., Görür, N., Çağatay, N., de Lepinay, B.M., Meyer, B., Saatçılar, R., Tok, B., 2001. The active main Marmara fault: comparative anatomy of a continental transform fault in a marine setting. Earth and Planetary Science Letters 192, 595-616.

Le Pichon, X., Şengör, A. C., Kende, J., İmren, C., Henry, P., Grall, C., \& Karabulut, H., 2015. Propagation of a strike-slip plate boundary within an extensional environment: the westward propagation of the North Anatolian Fault. Canadian Journal of Earth Sciences, 53(11), 14161439.

Lowe, D.R. 1979. Sediment gravity flows: their classification and some problems of application to natural flows and deposits. In: Doyle, L.J. and Pilkey, O.H. (Eds.), Geology of Continental Slopes. Society of Economic Paleontologists and Mineralogists, Special Publication 27, p. 7582.

Lowe, D. R., 1982. Sediment gravity flows: II Depositional models with special reference to the deposits of high-density turbidity currents. Journal of Sedimentary Research, 52(1).

Major, C., Ryan, W., Lericolais, G., \& Hajdas, I., 2002. Constraints on Black Sea outflow to the Sea of Marmara during the last glacial-interglacial transition. Marine Geology, 190(1-2), 19-34.

Masson, D.G., Arzola, R.G.,Wynn, R.B., Hunt, J.E.,Weaver, P.P.E., 2011. Seismic triggering of landslides and turbidity currents offshore Portugal. Geochemistry, Geophysics, Geosystems 12, 1-19. http://dx.doi.org/10.1029/2011GC003839. 
849

850

851

852

853

854

855

856

857

858

859

860

861

862

863

864

865

866

867

868

869

870

871

872

873

874

McClusky, S., Bassalanian, S., Barka, A., Demir, C., Ergintav, S., Georgiev, I., Gurkan, Hamburger, O.M., Hurst, K., Hans-Gert, H.-G., Karstens, K., Kekelidze, G., King, R., Kotzev, V., Lenk, O., Mahmoud, S., Mishin, A., Nadariya, M., Ouzounis, A., Paradissis, D., Peter, Y., Prilepin, M., Relinger, R., Sanli, I., Seeger, H., Tealeb, A., Toksoz, M.N., Veis, G., 2000. Global Positioning System constraints on plate kinematics and dynamics in the eastern Mediterranean and Caucasus. Journal of Geophysical Research 105 (B3), 5695-5719.

McHugh, C.M.G., Seeber, L., Cormier, M.-H., Dutton, J., Çağatay, N., Polonia, A., Ryan, W.B.F., Görür, N., 2006. Submarine earthquake geology along the North Anatolia Fault in the Marmara Sea, Turkey: a model for transform basin sedimentation. Earth and Planetary Science Letters 248, 661-684.

McHugh, C. M., Gurung, D., Giosan, L., Ryan, W. B., Mart, Y., Sancar, U., ... \& Cagatay, M. N., 2008. The last reconnection of the Marmara Sea (Turkey) to the World Ocean: a paleoceanographic and paleoclimatic perspective. Marine Geology, 255(1-2), 64-82.

McHugh, C.M., Seeber, L., Braudy, N., Cormier, M.-H., Davis, M.B., Diebold, J.B., Dieudonne, N., Douilly, R., Gulick, S.P.S., Hornbach, M.J., Johnson III, H.E., Ryan, K.M., Sorlien, C.C., Steckler,M.S., Symithe, S.J., Templeton, J., 2011. Offshore sedimentary effects of the 12 January 2010 Haiti earthquake. Geology 39, 723-726.

McHugh, C. M., Braudy, N., Çağatay, M. N., Sorlien, C., Cormier, M. H., Seeber, L., \& Henry, P., 2014. Seafloor fault ruptures along the North Anatolia Fault in the Marmara Sea, Turkey: Link with the adjacent basin turbidite record. Marine Geology, 353, 65-83.

Mulder, T., Tisot, J. P., Cochonat, P., \& Bourillet, J. F., 1994. Regional assessment of mass failure events in the Baie des Anges, Mediterranean Sea. Marine Geology, 122(1-2), 29-45.

Mulder, T., Syvitski, J.P.M., 1995. Turbidity currents generated at river mouths during exceptional discharges to the world oceans. Journal of Geology 103, 285-299.

Mulder, T., \& Cochonat, P., 1996. Classification of offshore mass movements. Journal of Sedimentary research, 66(1). 
875 Nakajima, T., Kanai, Y., 2000. Sedimentary features of seismoturbidites triggered by the 1983 876 and older historical earthquakes in the eastern margin of the Japan Sea. Sedimentary Geology $877135,1-19$.

878 Nemec, W., 1990. Aspect of sediment movement on step delta slope. In: Colella, A., Prior, D.B. 879 (Eds.), Coarse Grained Deltas. International Association of Sedimentologists Special 880 Publication, 10. Blackwell, Oxford, pp. 29-74.

881 Okay, A. İ., Kaşl1lar-Özcan, A., Imren, C., Boztepe-Güney, A., Demirbağ, E., \& Kuşçu, İ., 882 2000. Active faults and evolving strike-slip basins in the Marmara Sea, northwest Turkey: a 883 multichannel seismic reflection study. Tectonophysics, 321(2), 189-218.

884 Özeren, M. S., Çağatay, M. N., Postacioğlu, N., Şengör, A. C., Görür, N., \& Eriş, K., 2010. 885 Mathematical modelling of a potential tsunami associated with a late glacial submarine 886 landslide in the Sea of Marmara. Geo-Marine Letters, 30(5), 523-539.

887 Özhan, E., \& Abdalla, S., 2002. Türkiye Kıyıları için Rüzgar ve Derin Deniz Dalga Atlası. Kıyı 888 Alanları Yönetimi Türk Milli Komitesi, Ankara.

889 Parsons, T.S., Toda, T.S., Stein, R.S., Barka, A., Dietrich, J.H., 2000. Heightened odds of large 890 earthquakes near Istanbul, an interaction-based probability calculation. Science 288, 661-665.

891 Parsons, T., 2004. Recalculated probability of M>7 earthquakes beneath the Sea of Marmara. 892 Journal of Geophysical Research 109. http://dx.doi.org/10.1029/2003JB002667.

893 Pickering, K.T., Hiscott, R.N., 1985. Contained (reflected) turbidity currents in the Middle 894 Ordovician Cloridorme Formation, Quebec, Canada: an alternative to the antidune hypothesis. 895 Sedimentology 32, 373-394.

896 Polonia, A., Panieri, G., Gasperini, L., Gasparotto, G., Bellucci, L.G., Torelli, L., 2013a. 897 Turbidite paleoseismology in the Calabrian Arc subduction complex (Ionian Sea). 898 Geochemisty, Geophysics, $\quad$ Geosystems 14, 112-140. 899 http://dx.doi.org/10.1029/2012GC004402 
900 Polonia, A., Nelson, C. H., Romano, S., Vaiani, S. C., Colizza, E., Gasparotto, G., \& Gasperini, 901 L., 2017. A depositional model for seismo-turbidites in confined basins based on Ionian Sea 902 deposits. Marine Geology, 384, 177-198.

903 Pondard, N., Armijo, R., King, G. C., Meyer, B., \& Flerit, F., 2007. Fault interactions in the 904 Sea of Marmara pull-apart (North Anatolian Fault): earthquake clustering and propagating 905 earthquake sequences. Geophysical Journal International, 171(3), 1185-1197.

906

907

908

909

910

911

912

913

914

915

916

917

918

919

920

921

922

923

924

925

926

Postma, G., Babic, L., Zupanic, J., Roe, S.L., 1988. Delta-front failure and associated bottomset deformation in a marine, gravelly Gilbert-type delta. In: Nemec, N., Steel, R.J. (Eds.), Fan Deltas: Sedimentology and Tectonic Settings. Blackie, Glasgow \& London, pp. 91-102.

Pouderoux, H., Proust, J.N., Lamarche, G., Orpin, A., Neil, H., 2012a. Deep-sea sedimentation along the Hikurangi subduction margin (New Zealand) since the Last Glacial Maximum: characterisation, timing and origin of turbidites. Marine Geology 295e298, 51-76.

Pouderoux, H., Lamarche, G., Proust, J.-N., 2012b. Building a 18 000-year-long paleoearthquake record from detailed deep-sea turbidite characterisation in Poverty Bay, New Zealand. Natural Hazards and Earth System Sciences, 12, 1-25.

Prior, D.B., Suhayda, J.N., Lu, N.Z., Bornhold, B.D., Keller, G.H., Wiseman, W.J., Wright, L.D., Yang, Z.S., 1989. Storm wave reactivation of a submarine landslide. Nature 341, 47-50.

Provost, A. S., Chéry, J., \& Hassani, R., 2003. 3D mechanical modeling of the GPS velocity field along the North Anatolian fault. Earth and Planetary Science Letters, 209(3-4), 361-377.

Reilinger, R. E., McClusky, S. C., Oral, M. B., King, R. W., Toksoz, M. N., Barka, A. A., ... \& Sanli, I., 1997. Global Positioning System measurements of present-day crustal movements in the Arabia-Africa-Eurasia plate collision zone. Journal of Geophysical Research: Solid Earth, 102(B5), 9983-9999.

Reilinger, R., McClusky, S., Vernant, P., Lawrence, S., Ergintav, S., Cakmak, R., ... \& Nadariya, M., 2006. GPS constraints on continental deformation in the Africa-Arabia-Eurasia continental collision zone and implications for the dynamics of plate interactions. Journal of Geophysical Research: Solid Earth, 111(B5). 
927 Ruffine, L., Donval, J. P., Croguennec, C., Burnard, P., Lu, H., Germain, Y., ... \& Madre, D., 928 2017. Multiple gas reservoirs are responsible for the gas emissions along the Marmara fault network. Deep Sea Research Part II: Topical Studies in Oceanography.

930

Ryan, W. B., Pitman III, W. C., Major, C. O., Shimkus, K., Moskalenko, V., Jones, G. A., ... \& Yüce, H., 1997. An abrupt drowning of the Black Sea shelf. Marine Geology, 138(1-2), 119126.

Ryan, W. B., 2007. Status of the Black Sea flood hypothesis. In The Black Sea Flood Question: Changes in Coastline, Climate, and Human Settlement (pp. 63-88). Springer, Dordrecht.

Sakic, P., Piete, H., Ballu, V., Royer, J. Y., Kopp, H., Lange, D., ... \& Henry, P. 2016. No significant steady state surface creep along the North Anatolian Fault offshore Istanbul: Results of 6 months of seafloor acoustic ranging. Geophysical Research Letters, 43(13), 6817-6825.

Sar1, E., Çağatay, M.N., 2006. Turbidities and their association with past earthquakes in the deep Çınarcık Basin of the Marmara Sea. Geo-Marine Letters 26, 69-76.

Schnellmann, M., Flavio, S.A., Domenico, G., Judith, A.M., 2005. Mass movementinduced fold-and-thrust belt structures in unconsolidated sediments in Lake Lucerne (Switzerland). Sedimentology 52, 271-289.

Şengör, A.M.C., Tüysüz, O., İmren, C., Sakınç, M., Eyidoğan, H., Görür, N. Le, Pichon, X., Rangin, C., 2005. The North Anatolian Fault: a new look. Annual Review of Earth and Planetary Sciences 33, 37-112.

Shanmugam, G., 1997. The Bouma sequence and the turbidite mind set. Earth-Science Reviews, 42(4), 201-229.

Shiki, T., Kumon, F., Inouchi, Y., Kontani, Y., Sakamoto, T., Tateishi, M., Matsubara, H., Fukuyama, K., 2000. Sedimentary features of the seismo-turbidites, Lake Biwa, Japan. Sedimentary Geology 135, 37-50.

Siani, G., Paterne, M., Arnold, M., Bard, E., Metivier, B., Tisnerat, N., Bassinot, F., 2000. Radiocarbon reservoir ages in the Mediterranean Sea and Black Sea. Radiocarbon 42, 271-280. 
953

954

955

956

957

958

959

960

961

962

963

964

965

966

967

968

969

970

971

972

973

974

975

976

977

978

Straub, C., Kahle, H.-G., and Schindler, C., 1997. GPS and geologic estimates of the tectonic activity in the Marmara Sea region, NW Anatolia: Journal of Geophysical Research, v. 102, p. 27,587-27,601.

Uçarkuş, G., 2010. Active Faulting and Earthquake Scarps a Long the North Anatolian Fault in The Sea of Marmara (Doctoral dissertation, Avrasya Yer Bilimleri Enstitüsü).

Uçarkuş, G., Çakır, Z., \& Armijo, R. 2011. Western termination of the Mw 7.4, 1999 İzmit Earthquake rupture: Implications for the expected large earthquake in the Sea of Marmara. Turkish Journal of Earth Sciences, 20, 379-394.

Ünlülata, Ü., Oğuz, T., Latif, M. A., \& Özsoy, E., 1990. On the physical oceanography of the Turkish Straits. In The physical oceanography of sea straits (pp. 25-60). Springer, Dordrecht.

Van Morkhoven, F. P., Berggren, W. A., Edwards, A. S., \& Oertli, H. J. 1986. Cenozoic cosmopolitan deep-water benthic foraminifera (Vol. 11). Elf Aquitaine.

Vidal, L., Menot, G., Joly, C., Bruneton, H., Rostek, F., Çağatay, M. N., ... \& Bard, E. (2010). Hydrology in the Sea of Marmara during the last $23 \mathrm{ka}$ : implications for timing of Black Sea connections and sapropel deposition. Paleoceanography, 25(1).

Wentworth, C. K., 1922. A scale of grade and class terms for clastic sediments. The journal of geology, 30(5), 377-392.

Zitter, T. A. C., Henry, P., Aloisi, G., Delaygue, G., Çagatay, M. N., De Lepinay, B. M., ... \& Wallmann, K., 2008. Cold seeps along the main Marmara Fault in the Sea of Marmara (Turkey). Deep Sea Research Part I: Oceanographic Research Papers, 55(4), 552-570.

Zitter, T. A. C., Grall, C., Henry, P., Özeren, M. S., Çağatay, M. N., Şengör, A. M. C., ... \& Géli, L., 2012. Distribution, morphology and triggers of submarine mass wasting in the Sea of Marmara. Marine Geology, 329, 58-74.

\section{Figure Captions}

Fig 1. Location of the study and tectonic setting. A) Inset map shows current tectonic setting of Turkey and surroundings. B) High Resolution Multi-Beam Bathymetry Map of the Sea of 
979 Marmara (CB: Central Basin, CiB; Çınarcık Basin, CH: Central High, GI: Gulf of İzmit, KB:

980 Kumburgaz Basin, TB: Tekirdağ Basin, WH: Western High) (Revised from Uçarkuş, 2010).

981 Black lines represent the faults. Yellow box indicates the location of the Kumburgaz Basin (Fig.

982 2). Transparent lines represent Tekirdağ, Central High, Prince's Island and İzmit segments of 983 the NNAF with blue, red, green and yellow colors respectively. Dashed black line represents 984 the location of Constantinople.

985

986

987

Fig 2. Detailed bathymetry map of the Kumburgaz Basin and surroundings, showing locations of core CS-01 (yellow dot) and seismic reflection profile (Fig. 3) (red line). Faults are indicated with black lines. The main submarine canyons and depocenter in the basin are clearly shown in the inset map obtained by a slope gradient. (NWC: Northwestern Canyon, NC: Northern Canyon, NEC: Northeastern Canyon, WD: Western Depocenter, ED: Eastern Depocenter respectively).

Fig 3. Seismic reflection profile P02 from the Kumburgaz Basin, showing the main depositional units along the basin floor. Two different units are differentiated with different colors. Holocene marine unit and lacustrine unit are shown by blue and green color, respectively. Core CS-01 penetrates the upper half of the Holocene marine muds based on the core-to-seismic correlation. The wedge out of the marine sediments is obscured at NNAF close to NE of the profile.

Fig 4. Generalized sedimentary log of core CS-01 and radiographic images, showing the main lithostratigraphy of the Holocene marine unit deposited during the last 6.1 cal kyrs BP (Fig. 5). According to visual sedimentological observation on the core, we differentiated 28 seismoturbidite layers (ST-1 to ST-28), intercalating with hemipelagic/pelagic sediments. Red color within seismoturbidite unit represents the basal coarse-grained part, blue colored layers represent amalgamated turbidites, whereas yellow color is assigned to a homogenite part. Red stars indicate the ${ }^{14} \mathrm{C}$ sample locations with calibrated ages. 
1003

1004

1005

1006

1007

1008

1009

1010

1011

1012

1013

1014

1015

1016

Fig 5. Age-depth model for background sediment of the core CS-01 are reconstructed based on seven AMS ${ }^{14} \mathrm{C}$ ages by using Bacon.r Script. Red line represents the mean age of the iterations. Blue diamonds are the levels of the ${ }^{14} \mathrm{C}$ samples. Grayscale background indicates the iteration distribution. Black dash lines represent the position of the ST units.

Fig 6. Color image and radiography of the selected seismoturbidite layers (ST-4 and ST-13, $249 \mathrm{cmbsf}$ and $957 \mathrm{cmbsf}$ from base respectively) together with correlative plots of MS, gamma density, elemental profiles $(\mathrm{Mn} / \mathrm{Ca}, \mathrm{Fe} / \mathrm{Ca}, \mathrm{Ca}, \mathrm{K}, \mathrm{Sr})$ and combination of grainsize parameters (sorting, skewness, ratios of clay, silt and sand). Secondary sorting profile is focused on the background sediment and homogenite transition.

Fig 7. Color image and radiography of the selected amalgamated seismoturbidite layers (ST-6 and ST-7, $336 \mathrm{cmbsf}$ and $460 \mathrm{cmbsf}$ from base respectively) together with correlative plots of MS, gamma density, elemental profiles $(\mathrm{Mn} / \mathrm{Ca}, \mathrm{Fe} / \mathrm{Ca}, \mathrm{Ca}, \mathrm{K}, \mathrm{Sr})$ and combination of grainsize parameters (sorting, skewness, ratios of clay, silt and sand). 


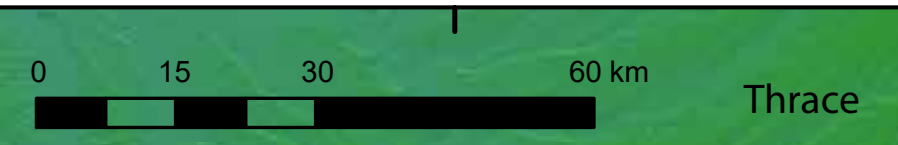

I

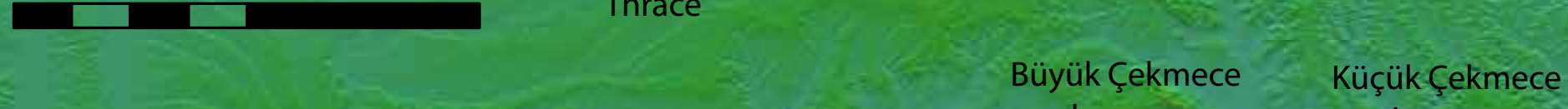

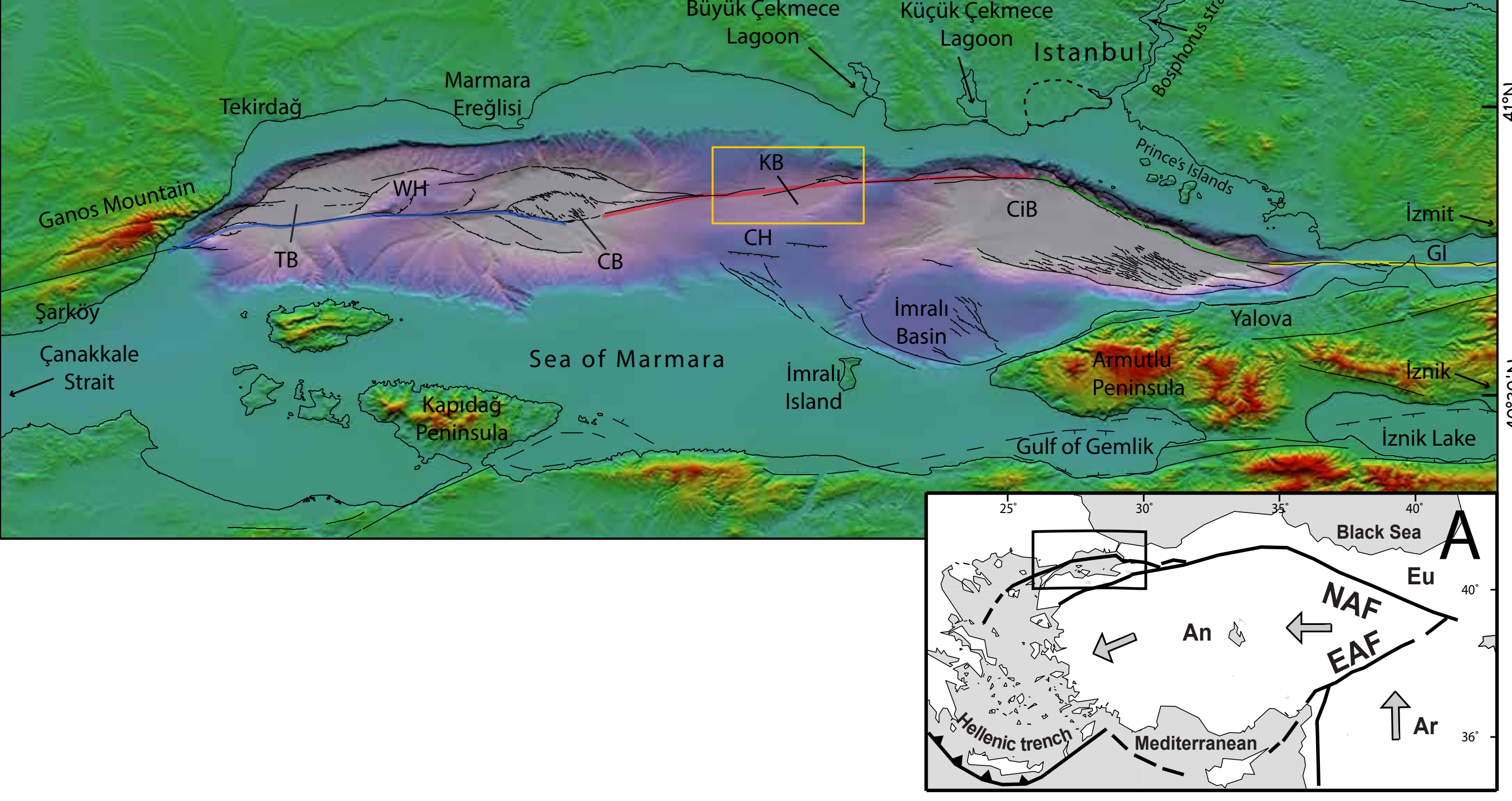




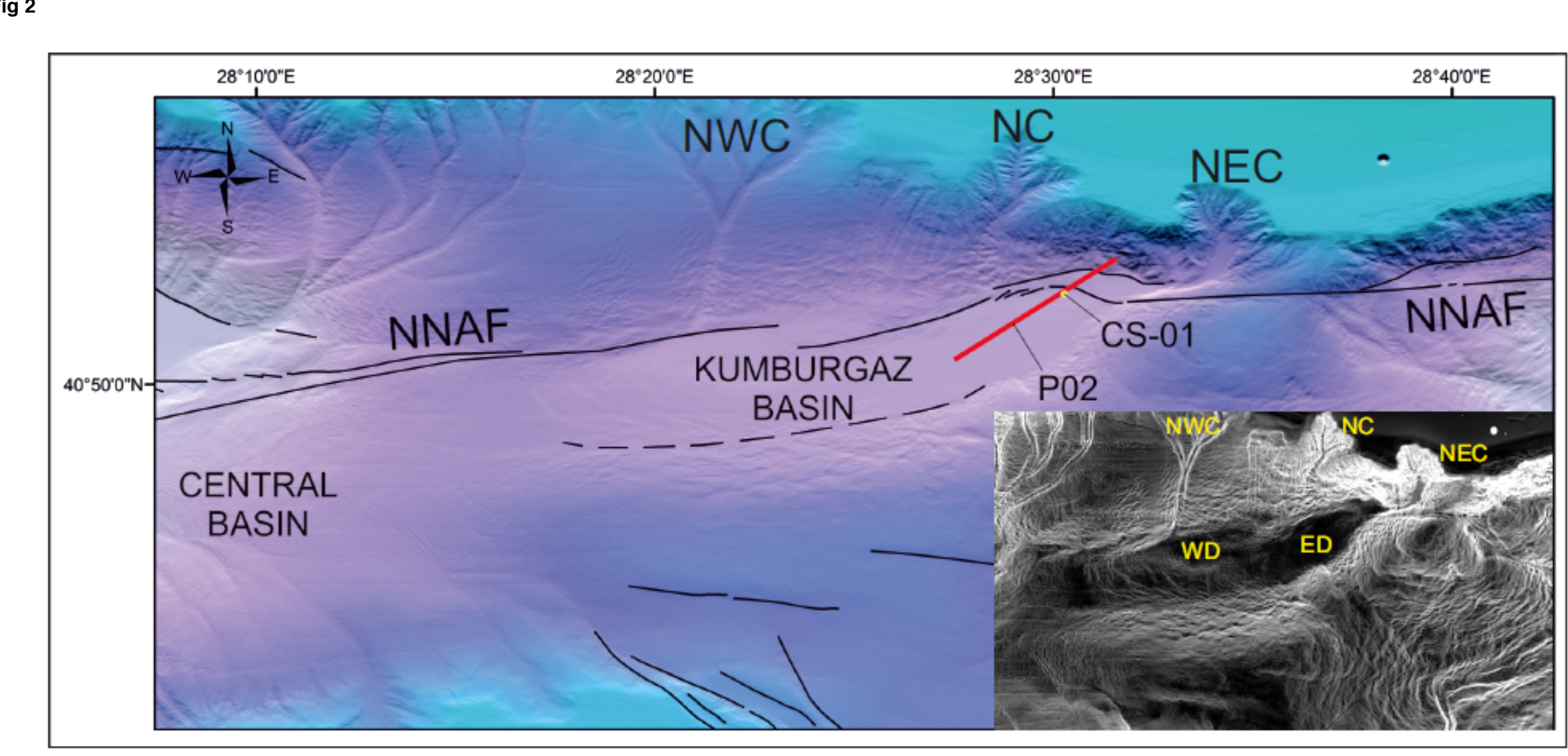

CENTRAL

\section{.

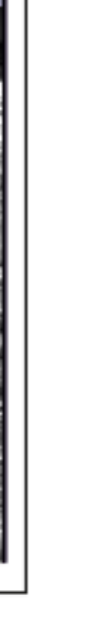

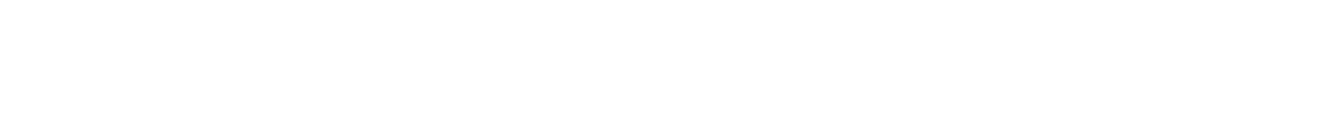
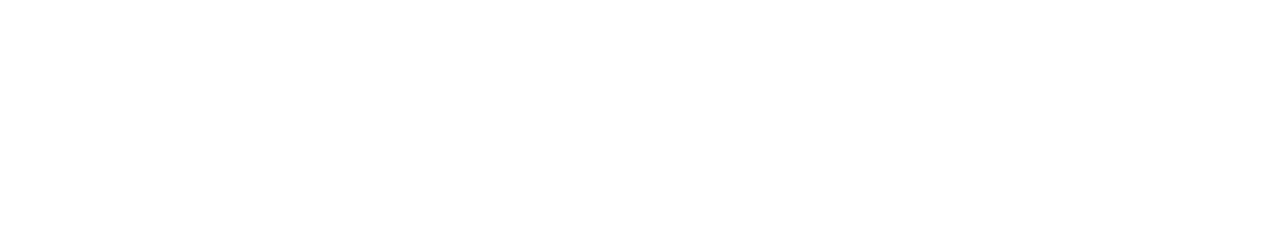
. 


\section{Fig 3}

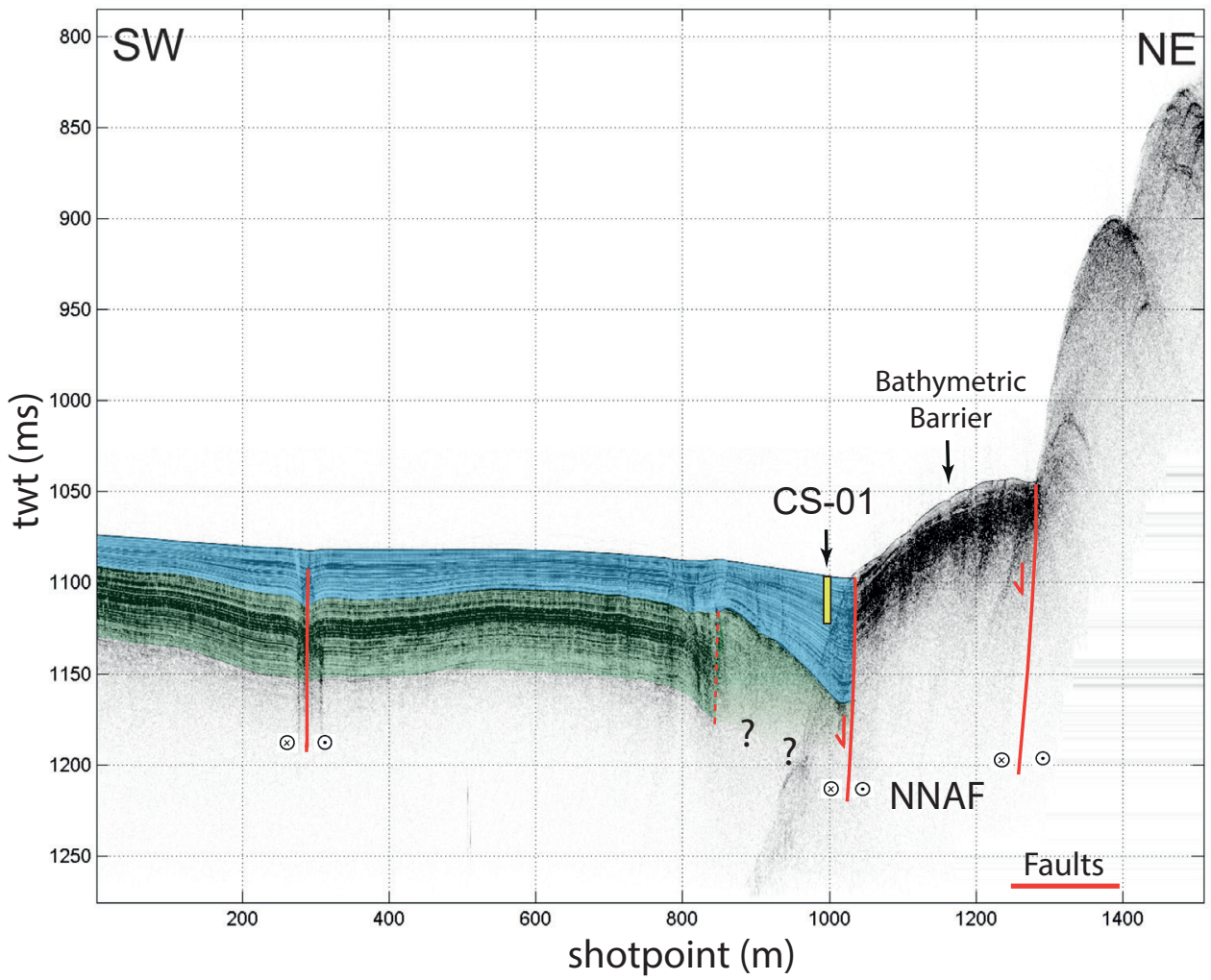




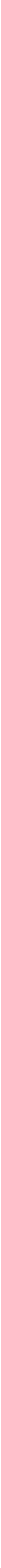




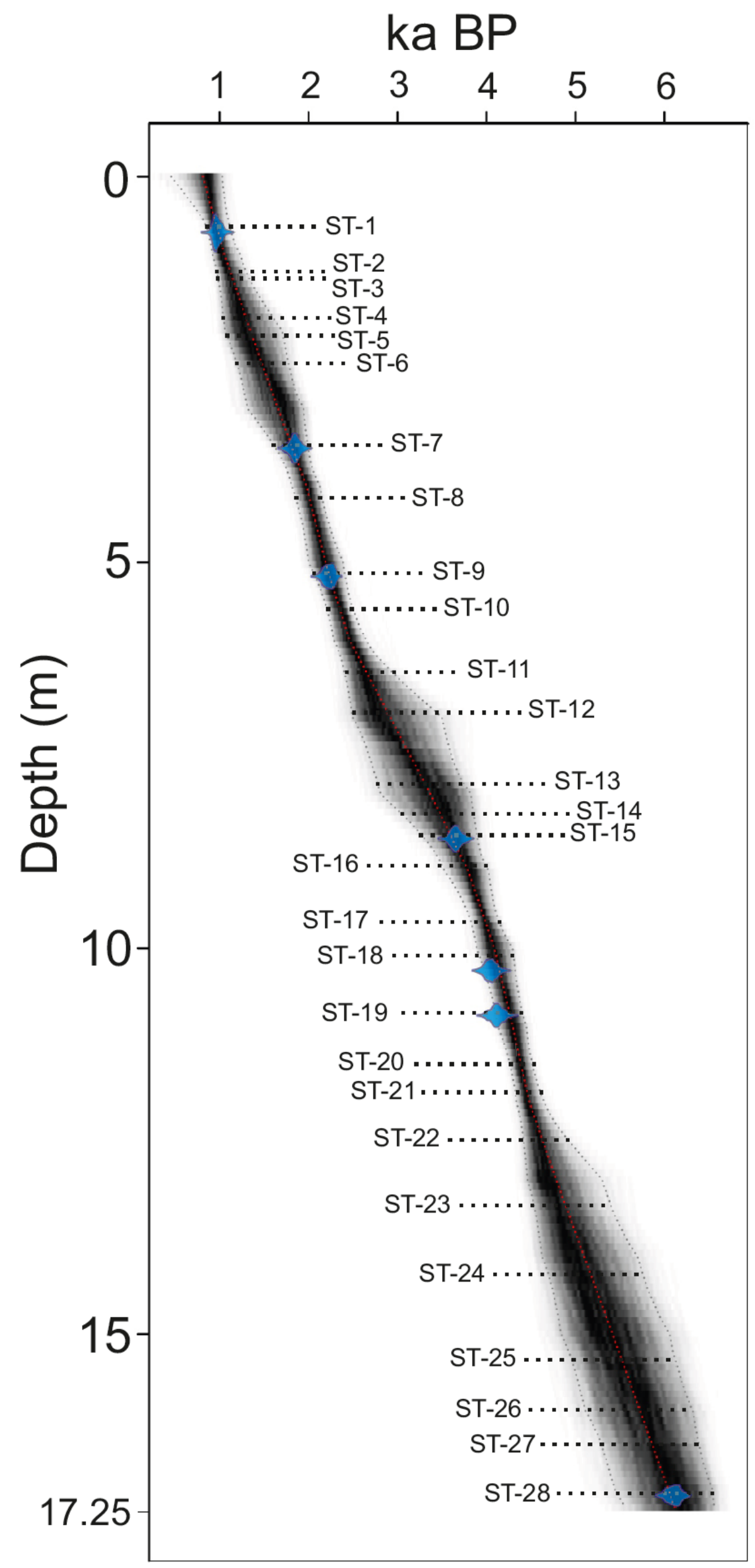



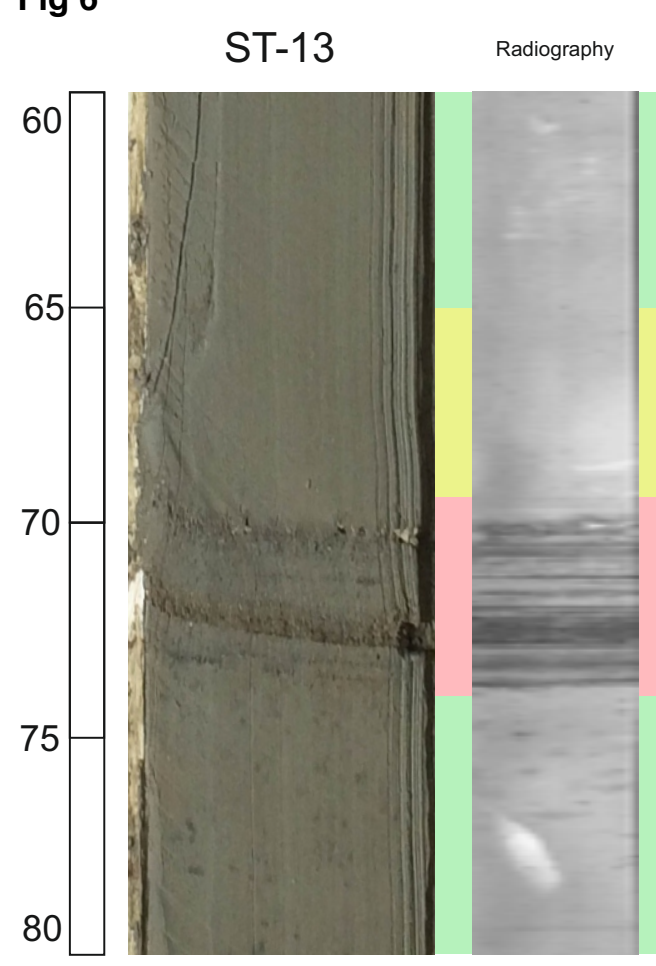

$\begin{array}{cc}\text { Magnetic } & \text { Gamma } \\ \text { Susceptibility } & \text { Density } \\ & \end{array}$

ST-4

Radiography

Magnetic
Susceptibility
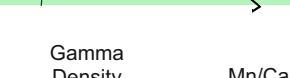

$\mathrm{Mn} / \mathrm{Ca}$
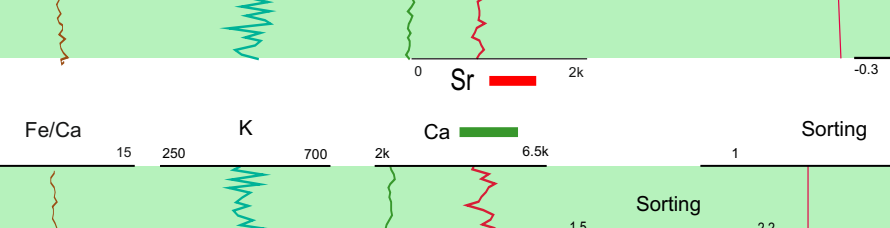

Skewness 0.4

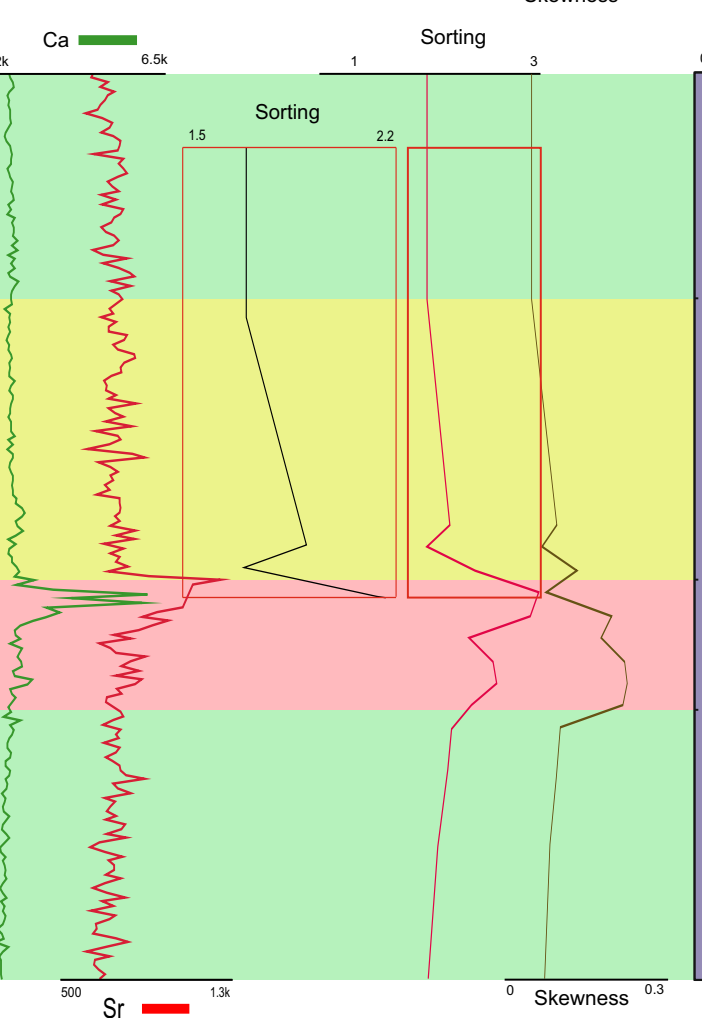

$\square>63 \mathrm{\mu m} \square 63.31 \mathrm{\mu m} \square 32-16 \mathrm{\mu m} \square$ 16-8 $\mathrm{\mu m}$ \% Relative $\square 8.4 \mu \mathrm{m} \quad \square 4.2 \mu \mathrm{m} \quad \square<2 \mu \mathrm{m}$

35
40
45
50
55
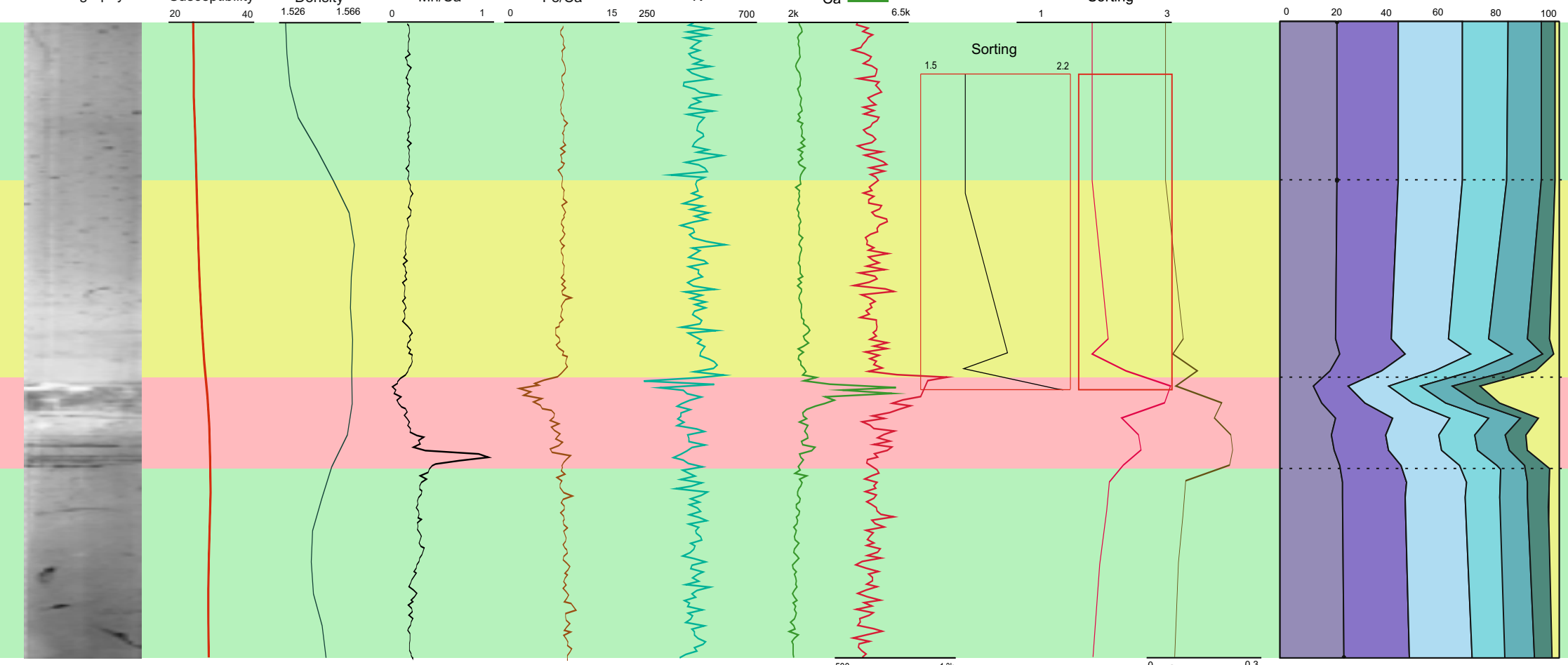

Hemipelagic

Homogenite

Coarse Basal Unit

Hemipelagic

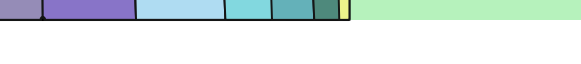


Table 1. Summary of AMS radiocarbon dates obtained from core CS-01. Reservoir correction applied as $\sim 390 \pm 85$ yrs. according to Siani et al. (2000).

\begin{tabular}{|c|c|c|c|c|}
\hline Sample Name & $\begin{array}{c}\text { Depth in Core } \\
(\mathbf{m m})\end{array}$ & $\begin{array}{c}\text { Depth in } \\
\text { background }\end{array}$ & $\begin{array}{c}\text { Uncalibrated } \\
\text { age (BP) }\end{array}$ & $\begin{array}{c}\text { Calibrated age } \\
\text { (BP) }\end{array}$ \\
\hline Age 1 & 1300 & 725 & $1505 \pm 30$ & $974 \pm 71$ \\
\hline Age 2 & 4639 & 3526 & $2325 \pm 35$ & $1836 \pm 103$ \\
\hline Age 3 & 6535 & 5181 & $2640 \pm 35$ & $2223 \pm 94$ \\
\hline Age 4 & 10469 & 8584 & $3815 \pm 35$ & $3666 \pm 113$ \\
\hline Age 5 & 12539 & 10291 & $4115 \pm 35$ & $4041 \pm 121$ \\
\hline Age 6 & 13155 & 10848 & $4160 \pm 35$ & $4105 \pm 123$ \\
\hline Age 7 & 20910 & 17092 & $5780 \pm 45$ & $6100 \pm 127$ \\
\hline
\end{tabular}


Table 2. Seismoturbidite age ranges based on age-depth model (Fig. 5).

\begin{tabular}{|c|c|c|}
\hline ST number & Depth (mm) & Mean (AD/BC) \\
\hline 1 & 1200 & $964,8 \mathrm{AD}$ \\
\hline 2 & 1780 & $820,5 \mathrm{AD}$ \\
\hline 3 & 1899 & $796,7 \mathrm{AD}$ \\
\hline 4 & 2495 & $658,6 \mathrm{AD}$ \\
\hline 5 & 2870 & $578,4 \mathrm{AD}$ \\
\hline 6 & 3367 & $464 A D$ \\
\hline 7 & 4605 & $135,9 \mathrm{AD}$ \\
\hline 8 & 5390 & $63,5 \mathrm{BC}$ \\
\hline 9 & 6510 & $284,3 \mathrm{BC}$ \\
\hline 10 & 7119 & $420,4 \mathrm{BC}$ \\
\hline 11 & 7950 & $701,4 \mathrm{BC}$ \\
\hline 12 & 8624 & $982,9 \mathrm{BC}$ \\
\hline 13 & 9577 & $1374,5 \mathrm{BC}$ \\
\hline 14 & 10140 & $560,3 \mathrm{BC}$ \\
\hline 15 & 10440 & 1658,4 BC \\
\hline 16 & 10965 & $1842 B C$ \\
\hline 17 & 11840 & $2060 \mathrm{BC}$ \\
\hline 18 & 12505 & 2190,7 BC \\
\hline 19 & 13140 & 2308,4 BC \\
\hline 20 & 14185 & 2444,9 BC \\
\hline 21 & 14605 & 2517,6 BC \\
\hline 22 & 15320 & 2687,2 BC \\
\hline 23 & 16405 & $2957 \mathrm{BC}$ \\
\hline 24 & 17490 & 3248,4 BC \\
\hline 25 & 18755 & $3576,5 \mathrm{BC}$ \\
\hline 26 & 19645 & $3797 \mathrm{BC}$ \\
\hline 27 & 20165 & 3915,2 BC \\
\hline 28 & 20875 & $4111,2 \mathrm{BC}$ \\
\hline
\end{tabular}


Table 3. Distribution of historical earthquakes and seismoturbidites found in CS-01 in correlation with other seismoturbidite based studies in the SoM. Abbreviations: a) McHugh et al., 2006, b) McHugh et al., 2014, c) This study, d) Drab et al., 2015, e) Çağatay et al., 2012, respectively. Note that, assigned letters corresponds the ST units that have been correlated with historical earthquakes.

\begin{tabular}{|c|c|c|c|}
\hline Central Basin & Kumburgaz Basin & Çınarckk Basin & Gulf of Izmit \\
\hline & & $1894 \mathrm{AD}(\mathrm{d})$ & \\
\hline & & $1509 \mathrm{AD}(\mathrm{d})$ & $1509 \mathrm{AD}(\mathrm{e})$ \\
\hline $1343 \mathrm{AD}(\mathrm{a}, \mathrm{b})$ & & $1343 \mathrm{AD}(\mathrm{d})$ & $1296 \mathrm{AD}(\mathrm{e})$ \\
\hline & & & \\
\hline & & $989 \mathrm{AD}(\mathrm{d})$ & $860-865 \mathrm{AD}(\mathrm{e})$ \\
\hline $860-865 \mathrm{AD}(\mathrm{b})$ & $869 \mathrm{AD}$ or $862 \mathrm{AD}(\mathrm{c})(\mathrm{ST} 2)$ & & $740 \mathrm{AD}(\mathrm{a}, \mathrm{e})$ \\
\hline $740 \mathrm{AD}(\mathrm{a})$ & $740 \mathrm{AD}(\mathrm{c})(\mathrm{ST} 3)$ & & \\
\hline $557 \mathrm{AD}(\mathrm{b})$ & $557 \mathrm{AD}$ or $554 \mathrm{AD}(\mathrm{c})(\mathrm{ST} 4)$ & & $358 \mathrm{AD}(\mathrm{e})$ \\
\hline & $447 \mathrm{AD}$ or $478 \mathrm{AD}(\mathrm{c})(\mathrm{ST} 5)$ & & $268 \mathrm{AD}(\mathrm{e})$ \\
\hline & $407 \mathrm{AD}(\mathrm{c})(\mathrm{ST} 6)$ & & $180-181 \mathrm{AD}(\mathrm{a})$ \\
\hline & & & \\
\hline & & & $427 \mathrm{BC}(\mathrm{e})$ \\
\hline
\end{tabular}

